\title{
Geology of the Copper River basin of south-central Alaska, 1977
}

Powell, J.D., McBride, R.T.J., and Amoco Oil Co.

GMC DATA REPORT 458

This GMC data report from the Amoco Heritage collection has been made available through funding from the FY2018 USGS National Geological and Geophysical Data Preservation Program, Grant Number G18AP00054. This project report is presented in its original format and has not been reviewed for technical content or for conformity to the editorial standards of DGGS. It should not be used or cited as reviewed data.

2019

State of Alaska

Department of Natural Resources

Division of Geological \& Geophysical Surveys

GEOLOGIC MATERIALS CENTER
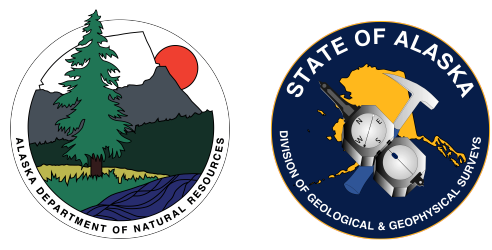


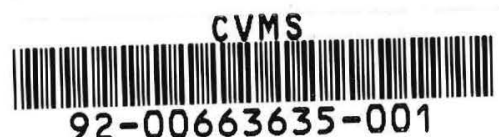

June 8,1977

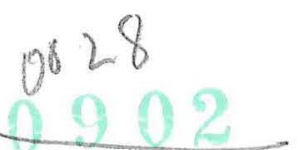

Re: Denver Division Geological Memorandum \#175 Copper River Basin of South Central Alaska and \#323 - Geological Update: Copper River Basin, Alaska

Mr. K. W. Ciriacks

BUILDING

Transmitted herewith is Denver Division Geological Memorandum \#175, "Copper River Basin of South Central Alaska", by J. D. Powell and Memorandum \#323, "Geological Update: Copper River Basin, Alaska", by R. T. J. McBride.

Both of these memos pertain to the regional geology found in the Copper River Basin and compile and expand on data obtained from the 1975 and 1976 field season. Results of this work show not only the geologic history of the basin but future hydrocarbon potentials of the Upper Triassic and Cretaceous horizons found there.

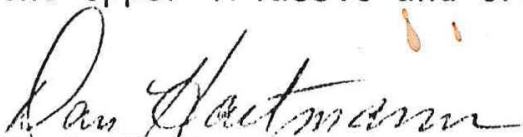

D. J. Hartmann

\section{DJH:SS}

APPROVED for transmittal by:

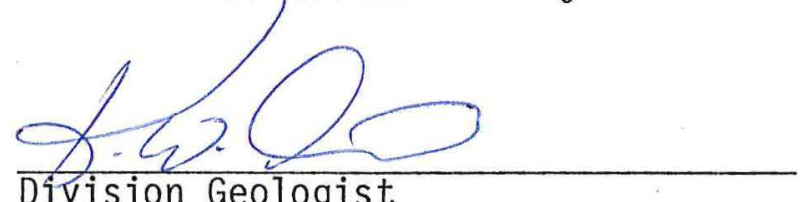

Authors: Memo \#175 - J. D. Powel1

Memo \#323 - R. T. J. McBride

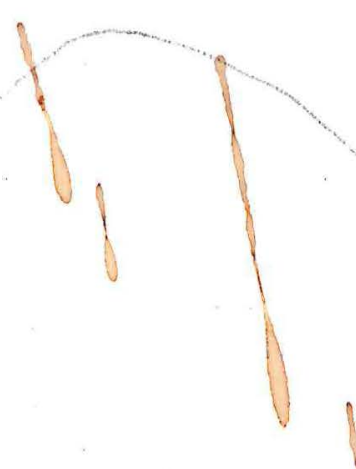




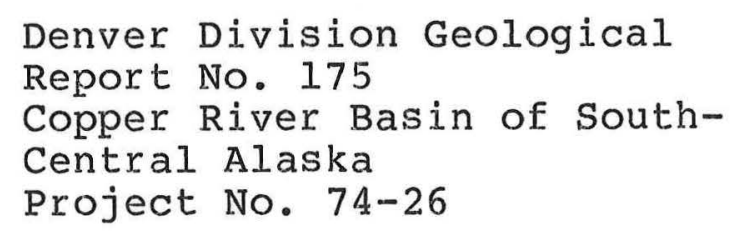

INTRODUCTION

General Discussion

Terrain

Accessibility

Purpose

Methods of Investigation

CONCLUSIONS

RECOMMENDATIONS

ENCLOSURES

REFERENCES

REGIONAL GEOLOGIC HISTORY

Discussion

\section{STRATIGRAPHY}

Regional Discussion

Subsurface Control

Surface Composite Stratigraphic Sections

PERMO-PENNSYLVANIAN

TRIASSIC

LOWER TRIASSIC

MIDDLE TRIASSIC

MIDDLE AND (OR) UPPER TRIASSIC

UPPER TRIASSIC

UPPER TRIASSIC - LOWER JURASSIC (?)

JURASS IC

LOWER JURASSIC

MIDDLE JURASSIC

UPPER JURASSIC

CRETACEOUS

LOWER CRETACEOUS

TERTIARY

TERTIARY-QUATERNARY

QUATERNARY

STRUCTURE

SOURCE ROCK EVALUATION

Author:

Doug Powell 


\section{INTRODUCTION}

\section{General Discussion}

The Copper River Basin is an intermontane basin located in south-central Alaska (Fig. 1) about 120 miles northeast of Anchorage via the Glenn Highway to its western edge. The basin is bounded by mountain ranges: the Alaska Range and its foothills to the north, the Wrangell Mountains to the east the Chugach Mountains to the south, and by the Talkeetna Mountains on the west.

Within the broadly defined region a much more restricted area is considered suitable for hydrocarbon exploration. The area considered most prospective is outlined by red tape on Enclosure 2 and contains about 110 Townships (2, 534,400 acres) or 3,960 square miles. The area averages about 50 miles in width, north to south, and about 82 miles in length. Black tape on Enclosures 1 and 2 encloses Amoco's contract area with the Ahtna Corporation which covers the approximate eastern half of the prospective basin.

\section{Terrain}

The forested and rolling topography of the contract area east of the Copper River is shown by photo nos. 73, 74 and 75 (Encl. 14). Photo no. 76 (Encl. 14) shows flat terrain in southeastern portion of the basin. The flat and rolling topography within part of the contract area west of the Copper River is shown in geological report No. 154 (1975, photos 1,2 , and 3). The many lakes, and heavily forested nature of the southwest portion of the basin is shown by photos 4 and 5 (Encl. 14). This type of terrain and large swampy areas are common throughout much of the basin.

\section{Accessibility:}

The basin is readily accessible by the all-weather Glenn Highway along the southern and northeast margins and the Richardson and Glenn-Richardson Highways (north-south) along the eastern margin. The partly paved Edgerton road extends into the southeast portion of the basin. The southern end of Lake Louise in the western part of the basin is accessible by a good gravel road.

\section{Purpose:}

The purpose of this report is to present the geology and the hydrocarbon potential of the Copper River Basin area as concluded from interpretation of field, subsurface, technical and published data and make recommendations for exploration in other prospective areas of the basins.

Geological Report No. 154 (Powell, 1975) was submitted as a final report to the Ahtna Corporation in November, 1975 and presented the geology chiefly concerning Amoco's contract area on which seismic program has been shot and additional seismic authorized for the 1976-1977 field season. This report revises and expands that report. 
This study was conducted under Project No. 74-26 to evaluate the hydrocarbon possibilities of the basin with primary emphasis on the stratigraphy of the Jurassic and the Lower Cretaceous.

\section{Methods of Investigations:}

A regional surface geology map (Powell, 1975, Encl. 1) was compiled primarily from U.S. Geological Survey data and includes to define the rock units within and around the Copper River Basin and to determine the outcrops available and accessible for field work.

A surface geological field program was conducted in the Copper River Basin area for eight weeks during July and August, 1974 , to study the stratigraphy of the prospective formations. A three-man crew (Grant Streeton and Dave Looney, geologists from Amoco Canada and the author) measured and collected samples from previously or newly measured sections to determine facies relationships and for paleontological studies (both micro and mega) to establish a time-stratigraphic framework, reservoir analysis and source rock analysis. Most of the data have been evaluated, with subsurface data incorporated into the interpretations.

During the latter part of July, 1976, a four-man field party consisting of Rick Haines, Bob McBride, Fritz Johnson and the author spent eight days in the western portion of the area (Nelchina Area) to collect additional samples for Geochem, paleontology, and reservoir analyses to help clear up correlation problems between megafossils and palynology, obtain more representative source rock data, and obtain porosity data on unsampled horizons, respectively. Several new sections were also measured and collected. This data has not yet been evaluated.

\section{CONCLUSIONS}

The Copper River Basin is prospective for oil and gas exploration, primarily in the Lower Cretaceous-Nelchina Formation and Upper Jurassic-Naknek Formation, because of favorable stratigraphy, potentially large structures, interpreted adequate source rocks, accessibility, pipeline and highway outlets, and favorable acreage situation as concluded from the specific qualities listed below:

1. Favorable Nelchina sandstone trends are interpreted across the basin (Encl. 1).

2. Outcrop and subsurface sections of the Nelchina sandstones demonstrate reservoir qualities.

a. Outcrop: Sandstone porosities range from $5.6 \%-24.3 \%$ and average $12.3 \%$; whereas, permeability varies from 0 Md to $669 \mathrm{Mds}$, and averages $58.1 \mathrm{Mds}$.

b. Subsurface: Porosity and permeability is indicated by water flows, with small amounts of gas, from the Nelchina Sandstones in the Mobil \#1 Salmon Berry Lake Unit (Section 24, T6N, R6W, CRM) and Pan American \#1 Moose Creek Unit (Section 29, T4N, R3W, CRM). A flow rate of $848 \mathrm{BWPH}$ was measured in the Moose Creek Well. 
3. Favorable Naknek Sandstone trends are interpreted in the western portion of the Copper River Basin. Their existence is questionable in the eastern portion of the basin (Encl. 2).

4. Naknek Sandstone porosities range from $3.2 \%-20.7 \%$ and average $11.59 \%$; whereas, their permeabilities vary from 0 Md to $196 \mathrm{Mds}$.

5. The Middle Jurassic-Tuxedni Formation is a secondary objective in the western portion of the basin. An eastward and southward facies change from sandstone to shale is interpreted (Encl. 3).

6. Tuxedni Sandstone porosities average 9.7\% and varies from $3.2 \%-19 \%$. The permeability averages $15.8 \mathrm{Mds}$ and ranges from 0 to $87 \mathrm{Mds}$. Of the five areas sampled, only the southeastern, North Horn Mountain Area, actually showed reservoir quality in a friable, fine to coarse grained quartz rich sandstone averaging $13.9 \%$ porosity (ranges from $7.5 \%-18.3 \%$ ) and $15.6 \mathrm{Mds}$ permeability (ranges from 0 Md-87 Mds).

7. Geophysical programs in the eastern part of the Copper River Basin (Ahtna Contract area) have mapped numerous structural leads.

8. The tectonism responsible for the structural configuration of the basin and the structural features mapped in the eastern part of the basin can be bracketed between Late Cretaceous and Tertiary Miocene time in the eastern part of the area and between Late Cretaceous and Early Tertiary (Paleocene-Eocene) to the west.

9. At present at least two of the seismic leads appears to be major arillable prospects.

10. Structural prospects can be tested at relatively shallow depths ranging from about 5,000' to a maximum of $10,000^{\prime}$.

11. The western Copper River Basin is equal to and probably exceeds the eastern part of the basin in stratigraphic potential.

12. The structural configuration and presence of structural trap are unknown in the western part of the basin.

13. The structural grain of the basin, based on available surrounding structural data indicates an arcuate pattern; that is, northeast trends on the west, west to east through midportion of basin, and northwest trends on the eastern flanks. The presence of large transverse or lateral faults cannot be precluded.

14. There is a significant conformity between the massimums and trends established by gravity and the mapped seismic structures in the eastern Copper River Basin.

15. Gravity should be used as the initial reconnaissance tool in the western part of the basin to delineate structural trends, and in designing seismic program and could prove valuable in selecting prospective acreage should Alaska open their lands for filing rather than competitive bids. 
16. There is definite evidence of migrated oil into the Lower Cretaceous-Nelchina Formation. There is good oil odor and oil-stained outcrop (up to $\left.700^{\prime}\right)$ on the west side of the basin and good odor and probable stain from the same formation on the east side of the basin. Within the basin a natural crude extract was analyzed from a Nelchina Formation sample taken from the Moose Creek well. Dead oil and asphalt have been reported from a lower shale zone of the Upper Cretaceous-Matanuska Formation.

17. Oil source rocks with poor to very good generating capabilities are present on the east side of the basin from shales of Upper, Middle and Lower Jurasic and Upper and Lower Cretaceous (Encls. 8 through 12) in past peak stage of diagenesis.

18. Oil source rocks with poor to fair generating capabilities are present on the west side of the basin from Upper Cretaceous shales, in past peak stage of diagenesis, and Upper Jurassic shales in a pregenerative stage of diagenesis. Absence of source rocks from the Jurassic and Lower Cretaceous, similar to the east side of the basin, may be due to a poor selection of samples, fewer samples, and weathering conditions. Additional samples were collected in July, 1976.

19. A possible oil capability is indicated from the Lower Cretaceous-Nelchina Formation at the Pan American No. 1 Moose Creek. The Nelchina extract is representative of a natural crude, although in conflict with the gas type kerogen as indicated by visual analysis. Harwood (1975, p. 2) points to the hydrogen value which is significantly higher than shallower samples and suggests an oil capability (this is probably migrated oil) along with the gas. The stage of diagenesis by visual analysis is near peak generation for oil and early generation for gas.

20. Gas and wet gas source rocks are present throughout the region from shales of Tertiary, Upper and Lower Cretaceous, Upper, Middle and Lower Jurassic, and Permian ages. Generating capabilities range from poor to very good. Samples east of the basin have much better capabilities than those to the west. Stages of diagenesis range from pregeneration (Tertiary), early generation (subsurface samples), and pregeneration to advanced, mostly early peak and peak (east and west sides) and advanced (Permian on north flank of basin).

21. The basin is readily accessible via all weather roads, the Glenn highway along the southern and northeast margins and the Richardson and GlennRichaxdson highways (north-south along the eastern margin).

22. Outlets for oil will be available by the Aleyska pipeline (July, 1977) and the highways.

23. Acreage blocks encompassing most of the significant structural features mapped in the eastern Copper River Basin can be assembled through the Ahtna Corporation, with which we have an exclusive hydrocarbon exploration contract. Amoco has until september 1977 to choose acreage. 
24. Acreage for oil and gas is unavailable at this time in the western part of the basin. This acreage is State of Alaska selection and at present it is unknown when or by what method Alaska will open this acreage for exploration, i.e., competitive bids or by drawing and filing.

25. Correlation problems within the Upper Jurasic exist between palynology and megafossils zones from outcrop samples on the western flank of the basin (as much as two stages off). Additional samples collected during July, 1976 may resolve this problem.

26. Correlation problems also exist in the subsurface between microfossils and palynology (see Encl. 6).

27. The Upper Cretaceous samples collected for palynology have not yet been evaluated.

\section{RECOMMENDATIONS}

1. Conduct a gravity survey on the western half of the Copper River Basin as outlined on Enclosures 1 and 2 by blue dashed at an estimated cost of $\$ 250,000$.

2. Conduct a five-month reconnaissance seismic program of the western half of the Copper River Basin, as outlined by dashed orange tape on Enclosures 1 and 2 at an estimated cost of $\$ 2,400,000$.

3. Restudy of microfossils (Eorams) in all wells in which samples are available.

4. The Upper Cretaceous outcrop samples collected for palynology should be evaluated.

\section{ENCLOSURES}

1. Lower Cretaceous-Nelchina Formation: Gross sand and trend map, scale 1:16,000, revised.

2. Upper Jurassic-Naknek Formation and coeval rocks: Facies and sand trend map, scale $1: 16,000$.

3. Stratigraphic correlation section: west to east, from the east flank of the Talkeetna Mountains to the Upper Chitina Valley area. H-H'.

4. West to east, stratigraphic cross-section of the Lower Cretaceous-Nelchina Formation from the Pan American No. 1 Moose Creek Unit to the southwest Wrangell Mountains. Revised G-G' of Report 154, Enclosure No. 6 .

5. Southwest to northeast, stratigraphic cross-section of the Upper Jurassic-Naknek Formation along the east flank of the Talkeetna Mountains. I-I'.

6. West to east, surface and subsurface correlation section from the Syncline-Sheep Mountain section to the southwest Wrangell Mountains, J-J'. 


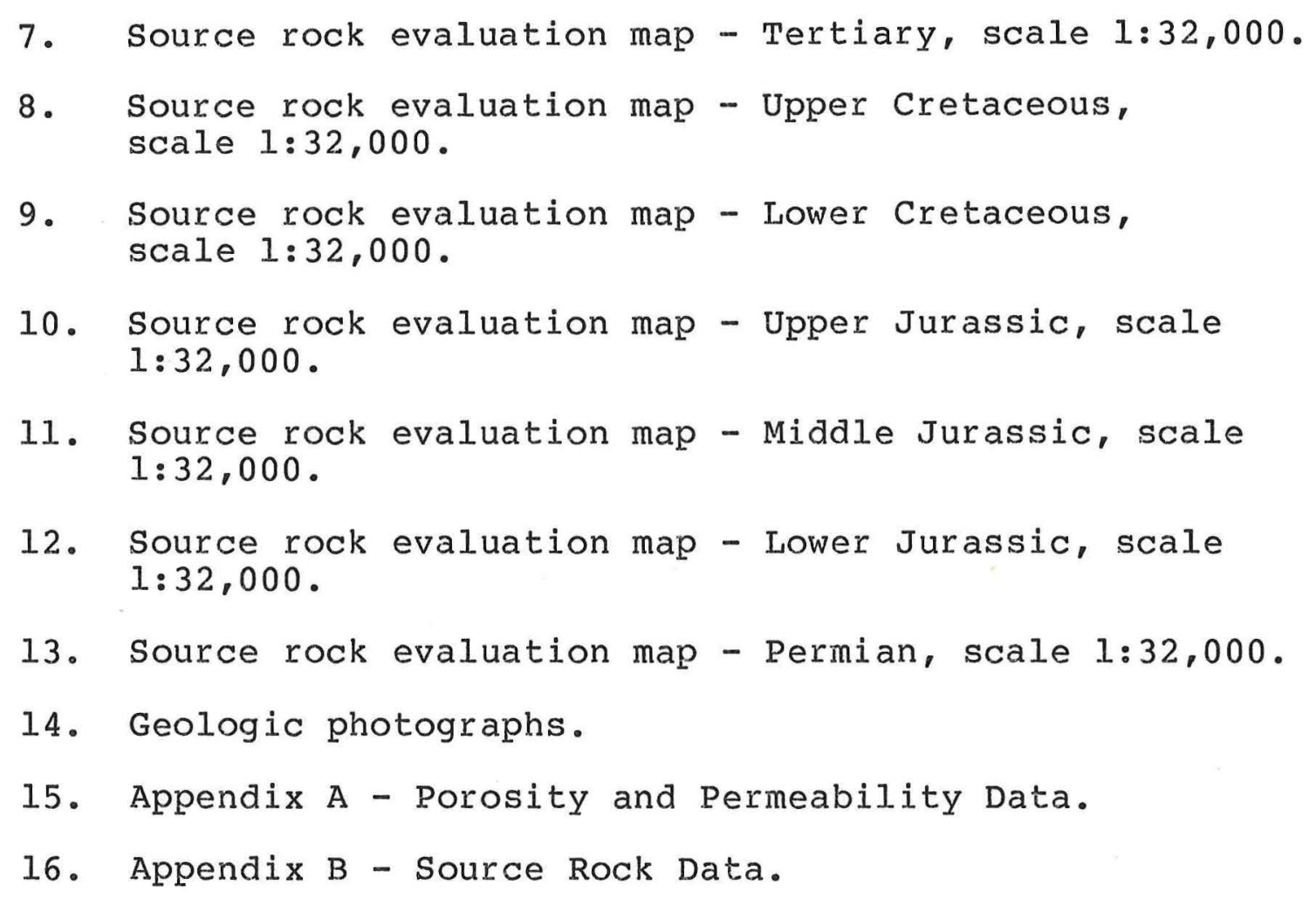

\section{Figures}

Figure 1, Index Map.

Figure 2, geologic column for the eastern Copper River Basin (Ahtna Contract Area).

Figure 3, Composite stratigraphic section for the west side of the Copper River Basin.

Figure 3, geologic column for the eastern Copper Rjver Basin.

Figure 4, composite stratigraphic section for the southwest Wrangell Mountains, east side of the Copper River Basin.

Figure 5, composite stratigraphic section for the Upper Chitina Valley (McCarthy Area).

\section{REFERENCES}

Armstrong, A. K., Mackevett, E. M., Jr., and Silberling, N.J., 1970, The Chististone and Nizina Limestones of part of the southern Wrangell Mountains, Alaska - a preliminary report stressing carbonate petrography and depositional environment in Geol. Survey Research 1969: U.S. Geol. Survey Prof. Paper. 650-D, p. D49D62.

Berg, H. C., Jones, D. L., and Richter, D. H., 1972, GravinaNutzotin belt - tectonic significance of an Upper Mesozoic sedimentary and volcanic sequence in southern and southeastern Alaska: U.S. Geol. Survey Prof. Paper 800D, P. D $1-D-24$.

Bishop, R. E., 1965, Cretaceous geology of the western Copper River Basin: Amoco Production Co., Anchorage District Geol. Report No. $11 \mathrm{~A}-11,5 \mathrm{p}$. 
Bond, G. C., 1973, A late Paleozoic volcanic arc in the eastern Alaska Range: Journal of Geology, vol. 81, p. 557-575.

Borax, E., Lian, H. M., and Wilson, T. Jr., 1958, Geology of the Upper Copper River Region, Alaska: Joint Report by Union Oil Co. of Calif. and the Ohio Oil Co. Honolulu Oil Corp. purchased report which subsequently became available to Pan Am Petr. Corp. via purchase of Honolulu Oil Corp. Amoco vault file No. SV 59-0403.

Byington, R. M., 1973, Source rock evaluation, Cretaceous and Jurassic cuttings samples, Mobil \#1 Salmon Berry Lake, Pan Am \#1 Moose Creek, Copper River Basin, Alaska: Amoco Production Company Research Center, Geochemistry Group-Technical Services $8642 \mathrm{CR}$ and $8649 \mathrm{CR}$, Jobs 9493 and 9490 .

Csejtey, Bela, Jr., 1976, Tectonic implications of a late Paleozoic volcanic arc in the Talkeetna Mountains, south-central Alaska: Geology, Vol. 4, No. 1, Jan.

Chapin, Theodore, 1918, The Nelchina-Susitna region, Alaska: U.S. Geol. Survey Bull. 668, 67 pp.

Derby, J. R., and Scott, R. W., 1974, Paleontological age determination and Paleoecology of 1974 Copper River Basin samples: Amoco Research Lab, Technical Service 5962 IR.

Detterman, R. L., Reed, B. L., and Lanphere, M. A., 1965, Jurasic plutonism in the Cook Inlet region, Alaska: U.S. Geol. Survey Prof. Paper 525-D, p. D16-D21.

Grantz, Arthur, 1953, Preliminary report on the geology of the Nelchina area, Alaska: U.S. Geol. Survey openfile report, 3 maps, 1 explanation, 9 figs. May 27, 1953.

1960a, Generalized geologic map of the Nelchina area, Alaska, showing igneous rocks and larger faults: U.S. Geol. Survey Misc. Geol. Inv. Map I-312.

1960b, Geologic map of Talkeetna Mountains $(\mathrm{A}-2)$ quadrangle, $\mathrm{Alaska}$, and the contiguous area to the north and northwest: U.S. Geol. Survey Misc. Geol. Inv. Map I-313.

- 1960c, Geologic map of Talkeetna Mountains ( $\mathrm{A}-1)$ quadrangle and the south third of Talkeetna Mountains (B-l) quadrangle, Alaska: U.S. Geol. Survey Misc. Geol. Inv. Map I-314.

196la, Geologic map and cross sections of the Anchorage (D-2) quadrangle and northeasternmost part of the Anchorage (D-3) quadrangle, Alaska: U.S. Geol. Survey Misc. Geol. Inv. Map I-342.

1961b, Geologic map of the north two-thirds of the Anchorage (D-1) quadrangle, Alaska: U.S. Geol. Survey Misc. Geol. Inv. Map I-343.

1964, Stratigraphic reconnaissance of the Matanuska Formation in the Matanusk Valley, Alaska: U.S. Geol. Survey Bull. 1181-1, 33 p., 3 figs. 
, 1965, Geologic map and cross sections of the Nelchina area, south-central Alaska: U.S. Geol. Survey open-file map, July 2, 1965, 4 sheets, scale $1: 63,360$.

, 1966, Strike-slip faults in Alaska:

U.S. Geol. Survey open-file report, 82 p., 8 figs.

Grantz, Arthur, and Jones, D. L., 1960, Stratigraphy and age of the Matanuska Formation, south-central Alaska, in Short papers in the geological sciences: U.S. Geol. Survey Prof. Paper 400-B, p. B347-B350.

Grantz, Arthur, Thomas, Herman, Stern, T. W., and Sheffey, N. B., 1963, Potassium-argon and lead-alpha ages for stratigraphically bracketed plutonic rocks in the Talkeetna Mountains, Alaska: U.S. Geol. Survey Prof. Paper 475B, p. B56-B59.

Grantz, Arthur, Jones, D. L., and Lanphere, M. A., 1966 , Stratigraphy, paleontology, and isotopic ages of upper Mesozoic rocks in the southwestern Wrangell Mountains, Alaska: U.S. Geol. Survey Prof. Paper 550-C, p. C39C -47 .

Harwood, R. J., 1975, Source rock evaluation of outcrop samples, Copper River Basin Area, Alaska: Amoco Prod. Co. Research Center, Geochemistry Group-Technical Service $9393 \mathrm{CK}$, Job 9421.

Imlay, R. W. and Detterman, R. L., 1973, Jurasic paleobiogeography of Alaska. U.S. Geol. Survey Prof. Paper 801.

Jones, D. L., 1964 (1963), Upper Cretaceous (Campanian and Maestrichtian) ammonites from southern Alaska: U.S. Geol. Survey Prof. Paper 432, 53 p., 45 pls., 25 figs., 2 tables.

, 1973, The Boreal Lower Cretaceous, Proceedings of an International Symposium: Geol. Journal Special Issue No. 5, December.

Jones, D. L., and Berg, H. C., 1964, Cretaceous stratigraphy of the McCarthy A-4 quadrangle, southern Alaska: U.S. Geol. Survey Bull. 1180-A, 18 p., 1 pl., 6 figs.

Jones, D. L., and Mackevett, E. M., Jr., 1969, Summary of Cretaceous stratigraphy in part of the McCarthy quadrangle, Alaska: U.S. Geol. Survey Bull. 1274-K, p. KI-KI9.

Jones, D. L., Mackevett, E. M., Jr., and Plafker, George, 1971, Speculations on Late Mesozoic tectonic history of part of southern Alaska (abs.): Internat. Symposium Arctic Geology 2d, San Francisco, Calif., 1971, p. 30.

McKevett, E. M., Jr., 1963, Preliminary geologic map of the McCarthy C-5 quadrangle, Alaska. U.S. Geol. Survey Misc. Geol. Inv. Map I-406.

\section{, 1965a, Preliminary geologic map of} the McCarthy $\mathrm{C}-5$ quadrangle, Alaska. U.S. Geol. Survey Misc. Geol. Inv. Map I-406.

\section{5b, Preliminary geologic map of} the McCarthy $\mathrm{C}-6$ quadrangle, Alaska: U.S. Geol. Survey Misc. Geol. Inv. Map I-438.

1969, Three newly named Jurassic formations in the McCarthy $\mathrm{C}-5$ quadrangle, Alaska: U.S. Geol. Survey Bull. 1274-A, p. 35-49, figs. 3-8. 
Martin, G. C., 1916, Triassic rocks of Alaska: Geol. Soc. America Bull., v. 27, p. 685-718.

, 1926, The Mesozoic stratigraphy of Alaska: U.S. Geol. Survey Bull., 776, 493 p.

Mendenhall, W. C., 1905, Geology of the central Copper River region, Alaska: U.S. Geol. Survey Prof. Paper 41, $133 \mathrm{p}$.

Miers, J. H., and Taylor, A. M., 1974, Geology and hydrocarbon potential of the Upper Tanana Basin: Denver Division Geol. Report 132 .

Miller, D. J., and MacColl, R. S., 1964, Geologic map and sections of the northern part of the McCarthy A-4 quadrangle, Alaska: U.S. Geol. Survey Misc. Geol. Inv. Map $I-410$.

Moffit, F. H., 1918, The upper Chitina Valley, Alaska: U.S. Geol. Survey Bull. 675, 82 p.

, 1938, Geology of the Chitina Valley and adjacent area, Alaska: U.S. Geol. Survey Bull. $894,137 \mathrm{p}$.

Moffit, F. H., 1938a, Geology of the Chitina Valley and adjacent area, Alaska: U.S. Geol. Survey Bull. 894, p. 16 pls., 1 fig.

1954, Geology of the eastern part of the Alaska Range and adjacent area: U.S. Geol. Survey Bull. 989-D, p. 65-218, pls. 6, 7, figs. 1840 .

Moffit, F. H., and Mertie, J. B., Jr., 1923, The KotsinaKuskulana district, Alaska: U.S. Geol. Survey Bull. 745.

Nichols, D. R., and Yehle, I. A., 1961, Mud Volcanoes in the Copper River basin, Alaska: in Geology of the Arctic, University of Toronto Press, p. 1063-1087.

, 1969, Engineering geologic map of the southeastern' Copper River Basin, Alaska: U.S. Geol. Survey Misc. Geologic Investigations Map I-524.

Payne, T. G., 1955, Mesozoic and Cenozoic tectonic elements of Alaska: U.S. Geol. Survey Misc. Geol. Inv. Map I84 scale $1: 5,000,000$.

Powell, Doug, 1975, Geological Report to the Ahtna Corporation, Copper River Basin, South-Central Alaska: Denver Division Geological Report No. 154, Project No. 74-26, November.

Richter, D. H., 1971, Reconnaissance geologic map and section of the Nabesna B-4 quadrangle, Alaska: U.S. Geol. Survey Misc. Geol. Inv. Map I-656.

1973, Preliminary bedrock geologic map of the Nebesna quadrangle, Alaska: U.S. Geol. Survey open-file map, 1 sheet, scale 1:250,000.

1976, Geologic Map of the Nebesna quadrangle, Alaska: U.S. Geol. Survey Misc. Inv. Series, Map I-932, 1 sheet, scale 1:250,000.

Richtex, D. H. and Dutro, J. T., Jr., 1975, Revision of the type Mankomen Formation (Pennsylvanian and Permian), Eagle Creek area, eastern Alaska Range, Alaska: U.S. Geol. Survey Bull. 1395-B, p. B1-B25. 
Richter, D. H., and Jones, D. L., 1973, Structure and stratigraphy of eastern Alaska Range, Alaska: Arctic Geology, Memoir, No. 19, Am. Assoc. of Petroleum Geologists.

Shaw, B. E., 1960, Preliminary evaluation of the oil and gas possibilities of the Copper River basin, Alaska: Amoco Production Co., Anchorage District Geol. Rept. No. XAB-5.

Smith, J. G., and Mackevett, E. M., Jr., 1970, The Skolai Group in the McCarthy $\mathrm{B}-4, \mathrm{C}-4$, and $\mathrm{C}-5$ quadrangles, Wrangell Mountains, Alaska: U.S. Geol. Survey Bull. $1274-Q$, p. Q1-Q26.

Smith, T. E., 1974, Regional Geology of the Susitna-MacLaren River Area: Alaska Geological and Geophysical Surveys Ann. Rept., 1973, p. 3-6.

Smith, T. E., and Lanphere, Marvin A., 1971, Age of the sedimentation, Plutonism, and regional metamorphism in the Clearwater Mountains Region, Central Alaska: Isochron/West, No. 2, August, 1971.

Smith, T. E. and Turner, D. L., 1973, Geochronology of the McClaren Metamorphic Belt, South-Central Alaska; a progress report: Isochron/West, No. 7, August, 1973.

Van Hinte, J. E., 1976, A Jurassic time scale: AAPG Bull. Vol. 60, No. 4, April, 1976, p. 489-497.

1976, A Cretaceous time scale:

AAPG Bul1. Vol. 60 , No. 4, April, 1976, p. 498-516. 
Discussion:

As both structural and stratigraphic events are covered in this discussion, the east to west regional correlation cross section (Encl. 3) and the geologic map (Denver Division Report 154, Encl. 1) will be helpful references.

During the late Paleozoic Era, southern Alaska was a region of eugeosynclinal deposition (now being referred to as a Volcanic Arc). A thick sequence of volcanic and volcaniclastic rocks were deposited during the late Pennsylvanian and Early Permian Periods (Smith and Mackevett, 1970, Richter and Jones, 1973, and Csjtey, 1976). Emplacement of late Pennsylvanian granitic type plutons are documented in the eastern Alaska Range. The Pennsylvanian deposits are considered the basement complex for the region south of the Denali. Fault. Shallow to deep marine sedimentation continued during Early to middle Permian time in the eastern and northeastern parts of the region; whereas, volcanic arc deposition persisted to the west and northwest.

Uplift, plutonism, metamorphism and erosion marked most of the area during middle Permian to Middle Triassic time. Early Triassic volcaniclastic and limestones and Middle Triassic limestones and calcareous siltstone, probably representing intermixing of "Arc" and marginal marine sedimentation, are reported to the far northwest, in the Upper Chulitna District (Clark, Clark and Hawley, 1972).

During Middle and Late Triassic time subaerial volcanism occurred on the continental platform to the east depositing the thick Nikolai Greenstones lava flows and minor basal conglomerates) followed by thick, marine carbonates and shales sedimentation on a "drowning" platform. Submarine volcanism intermixed with shallow marine sedimentation (Clark, et al, 1972, Smith, 1971, 1974) persisted to the west.

A volcanic arc present in the western part of the Copper River basin during the Lower Jurassic deposited the Talkeetna Formation - a thick sequence of volcanics and volcaniclastics - in the Talkeetna and northern Chugach Mountains. At the same time, to the east in the southern Wrangell Mountains, deeper marine to nearshore shales, argillites, cherts, limestones, coquinas and spiculites of the upper member of the McCarthy and Lubbe Creek Formations were deposited (Imlay and Detterman, 1973). The area to the north was positive or the sediments have been eroded.

Near the end of the Lower Jurassic time the rocks of the eugeosyncline were deformed, intruded by the granitic Kosina batholith in the Talkeetna Mountains (Grantz and others, 1963) and metamorphosed by a period of orogeny which created provenance areas in the Talkeetna Mountains and probably to the north and northeast, and at the same time formed the Matanuska geosyncline (Payne, 1955) in which the prospective rocks of the Copper River Basin were deposited.

Unstable shelf sedimentation commenced and persisted during Middle and lower Upper Jurassic time with intraand interformational unconformities common. Much volcanic material is seen in the clastic sediments which become more quartzose as the Kosina batholith or allied plutons are unroofed. A quartzose sandstone on the north flank of Horn Mountain uplift (Nelchina Area) suggests that at least part of the intrusive complex was uncovered in early TuxedniBajocian time. 
Uplift and erosion during late Bajocian time removed lower Tuxedni and coeval deposits from the southern and eastern Copper River Basin, western half of the Wrangell Mountains and along the northern Chugach Mountains and Upper Chitina Valley.

Continental, nearshore and shallow marine shelf sedimentation occurred in upper Middle Jurassic-Bathonian time. These upper Tuxedni deposits overlapped the Bajocian rocks to the north (Grantz, 1953, 1965). The Nizina Mountain Formation was deposited in the Wrangell Mountains with no apparent break between the Lower Jurassic and upper Middle Jurassic (Mackevett, 1971, 1972 and Imlay and Detterman, 1973).

The unstable nature of the shelf area is again apparent by uplift and erosion in late Middle to early Upper Jurassic time followed by marine sedimentation which deposited near shore conglomerates and sandstone and shallow marine sandstones, siltstones, shales and mudstone of the Chinitna Formation unconformably on the Tuxedni Group, but with no apparent angular discordance. Callovian (?) age (lower Upper Jurasic) rocks were originally reported in the southern Wrangell (Mackevett, 1971, 1972) but since have been placed in the Middle Jurassic (Imlay and Detterman, 1973).

Major uplift, folding (?) and erosion occurred near the end of the lower Upper Jurasic (Callovian to Oxfordian) time. The unconformity is much more pronounced to the east, in the southern Wrangells and Upper Chitina Valley, south along the northern Chugach, and northern perimeter of the basin. Northwest and northeast trending (present trends) basins or trenches began to form north of the Wrangell Mountains (Eastern Alaska Range-Nuzotin Mountains of Richter, 1973) and in the Upper Susitna Valley, both south of the "present day" Denali Fault.

During the Upper Jurassic, continental (?), coastal and shallow shelf to deeper marine sediments were deposited in the Copper River Basin, unconformably overlying lower Upper Jurassic, Middle and Lower Jurassic deposits in the Talkeetna Mountains and deposits of Middle Jurassic to Upper Triassic age in the Wrangell Mountains. Parts of the Talkeetna and Wrangell Mountains (possibly connected around the northern portion of the basin) were positive source areas that supplied sediments southward onto the shelf area and also northward into the deep basins as nonmaxine, shallow and deep (Turbidites) marine deposits of the eastern Alaska Range and probably the same in the Upper Susitna Valley. A northernmost source area, the metamorphosed terrane north of the Denali Fault also supplied sediments southward (Richter, 1976) into the trench area. An ophiolitic assemblage of serpentinite, gabbro, basalt, bedded chert and siliceous argillite mapped in the Upper Chulitna district as (?) Permian are identified as Late Jurassic or older (Csejtey, 1976).

The end of the Jurassic Period was marked by uplift, folding, plutonism and erosion which is more pronounced in the eastern and southern margins of the basin. Deep water sedimentation (turbidites) continued in the trenches to the northeast and northwest.

During Lower Cretaceous-Neocomian time shallow marine shelf sedimentation returned to the unstable area, depositing the sandstones, conglomerates and limestones of the Nelchina Formation (major objective) across the Copper River Basin, possibly embaying northward or slightly around the Talkeetna and Wrangell positive areas. No connections can be demonstrated (other than age) with the trenches to the northeast and 
northwest. In the northeastern basin a thick unit (Chisana Formation) of marine and subaerial volcanics and volcaniclastic rocks (volcanic arc assemblage - Richter, 1976) were deposited. Deposits equivalent to the volcanic arc sequence are not known in the northwestern basin area (Clark and others, 1972).

The basin area was uplifted and eroded near the end of the Neocomian time. Along the southern margin of the basin and the northern Chugach, the entire Nelchina Formation has been removed, only a few outliers remain on the Chugach Mountains across the Copper River Valley, east of Chitina. In many areas it is difficult to determine how much of the section missing is due to post Neocomian erosion, as post Cretaceous erosion or nondeposition could be the cause.

Upper Neocomian (Barremian Age) rocks are recognized in the northeastern trench (Richter, 1976) and in the western Wrangell Mountains, but have been removed in the Nelchina Area (Talkeetna Mountains). Rocks of Aptian age have not been found in southern Alaska (Jones, 1973).

In Albian time of the Lower Cretaceous, continental, nearshore to shallow marine sediments were deposited. No Albian age rocks are reported in the eastern Alaska Range or Upper Susitna River trenches. Evidence for the unconformity between Neocomian and Albian is marked by the absence of Upper Neocomian beds in the Talkeetna Mountains and reworked upper Neocomian fossils in the basal Albian in the western Wrangell Mountains, but no marked structural discordance. Along the northern front of the Chugach Mountains in the southwestern part of the basin the basal beds of the Matanuska Formation (of Albian Age) unconformably onlap the Lower Jurassic-Talkeetna Formation. Nearshore to shallow marine deposits are reported along the front of the Chugach (Grantz, 1960, 1974). The higher parts of the Chugach, Talkeetna, and Wrangell Mountains and the area to north of the basin were positive during Albian time. Although Albian Age rocks are present on the east, west and southwest flanks of the basin, microfossils of definite Albian age have not been identified in the Copper River Basin subsurface.

During the Upper Cretaceous, shelf to deep water sedimentation prevailed. A large positive area exists around the northern part of the basin. The Chugach was sporadically positive (Grantz, 1960). Upper Matanuska sandstones (secondary objective) of deep water origin are present on syncline Mountain in the Nelchina Area. A marine to continental interface should be present both in the northern and southern parts of the basin, unless destroyed by post-Cretaceous erosion.

Major uplift, folding, faulting, plutonism, and erosion occurred during Late Cretaceous to early Tertiary-Paleocene time (time of Laramide orogeny). The Paleocene-Chickø̆loon Formation unconformably overlies oldex rocks in the Nelchina Area. The Paleocene to Miocene sediments (if deposited) have been eroded from the remainder of the Copper River Basin Area.

These tectonic events are responsible for the structural framework of the present day Copper River Basin, structures mapped in the Ahtna contract area, as well as the strongly folded and faulted trench deposits of the eastern Alaska Range and the Upper Susitna River Area.

In early Miocene time continental sedimentation prevailed throughout the region. From late Tertiary-Miocene to Quaternary, the region was marked by Continental volcanism, depositing 
the Wrangell lavas and coeval extrusives, plutonism, regional uplift and the extensive glaciation that we see today began in Quaternary time. Evidence for Miocene glaciation in the northeast Wrangell Mountains was reported by Richter (1972).

\section{STRATIGRAPHY}

\section{Regional Discussion}

The depositional history of the Copper River Basin region began in Late Paleozoic-Pennsylvanian time with the forming of a volcanic arc system directly on oceanic crust (Richter and Jones, 1973). This arc or arc systems persisted, intermixed or alternated with marine clastics and carbonates in various parts of the region, apparently not continuous in any single area, through Permian, Triassic and Lower Jurassic time (Ibid, Clark and others, 1972; Csejtey, 1976).

Major tectonism at the end of the Lower Jurassic formed the Matanuska syncline (Payne, 1955) in which the prospective rocks of the Copper River Basin were deposited. From Middle Jurassic into Upper Cretaceous time nearshore and rather shallow basin sediments were deposited along an unstable shelf as evidenced by numerous unconformities. During Late Jurassic and Early Cretaceous, shallow to deep water (turbidites) were deposited in the eastern Alaska Range and Nuzotin Mountain (Richter and Jones, 1973, Miers and Taylor, 1975) and probably in the Upper Chulitna district (Clark and others, 1972). A thick sequence of marine and subaerial volcanics and volcaniclastics (volcanics arc assemblage) were deposited during the remainder of the Lower Cretaceous in the eastern Alaska Range (Richter and Jones, 1973). The more basinal Matanuska Formation and coeval rocks were deposited in the Upper Cretaceous seaway of the Copper River Basin and Upper Chitina Valley area. Regression and uplift with folding occurred at the end of the Cretaceous time. This resulted in a depositional and structural belt which essentially parallels the present arcuate coast line. Nonmarine sedimentation and volcanism prevailed through Tertiary and Quaternary time with regional uplift and minor folding in Late Tertiary time.

\section{Subsurface Control}

Eight wells have been drilled for hydrocarbons in the Copper River Basin since 1975 for a drilling density of one well per 14.6 townships (525.6 square miles). Only two tests have penetrated the Lower Cretaceous-Nelchina Formation (Encl. 1), which is the main objective. Other tests have failed to penetrate the main objectives, objectives eroded, or in unfavorable facies. See Enclosure 6 for subsurface correlation of the deeper tests.

Oil and gas shows have been reported from three tests. The Aledo \#l Eureka (Section 10, T2IN, RI2E, SM), located in the extreme southwest part of the basin, drilled to 4,818' in the Upper Cretaceous, and recovered two quarts "dead" oil and asphalt from a sandy shale zone of the Matanuska Formation. The Mobil \#1 Salmon Berry Lake Unit (Section 24, T6N, R6W, CRM, located near the centxal portion of western part of the basin, drilled to 7,913' in the Lower JurassicTalkeetna Formation and encountered a salty water flow (21,600 PPM) with a slight gas show in the Nelchina Formation. The Middle Jurassic-Tuxedni Formation and the Upper Jurassic-Chinitna and Naknek Formations were all in the shale and siltstone facies. The third well, Pan American \#1 Moose Creek Unit 
(Section 29, T4N, R3W, CRM) most eastern located test, drilled to $7,869^{\prime}$ in the Talkeetna Formation and encountered a slight gas show and salty water $(16,000$ PPM) flow from the Matanuska Formation at 5,430' and blew out and flowed salty water $(18,322 \mathrm{PPM})$ at the rate of $848 \mathrm{BWPH}$ with minor gas.

No commercial production has been established to date and it is unknown if an optimum structural closure has been tested. Several water wells have been drilled. Of local interest is the one dxilled in about the center of the south line of Section 21, T4N, R2W, CRM, which drilled to 160' and flowed gas at 970 MCFGP initially and at 640 MCFGPD after two weeks. The gas analyzed at $67 \%$ methane and $32 \%$ nitrogen with some hydrogen-sulphide reported and is probably from Quaternary marsh beds?

\section{Surface Composite Stratigraphic Sections}

Due to truncation and nondeposition, the thicknesses of the composited geologic column ranges from 31,000'+ to $47,500^{\prime}+$ around the basin margin. It is anticipated that an average thickness of 10,000' of Quaternary through (?) Middle Jurassic sediments can be expected in the deeper portions of the basin. Three composite stratigraphic sections are incorporated with subsurface control into a correlation section (Encl. 3) across the basin, showing the vertical distribution of the formations and the structural implications.

\section{Talkeetna Mountains}

On the west side of the basin the composite stratigraphic section attains a thickness of about 44,305' of Permo-(?) Pennsylvanian through Quaternary age sediments (Fig. 3). Approximately 20,000' of Middle Jurassic through Quaternary age rocks, which covers the prospective formations, were deposited. The altered to metamorphosed volcanics and volcaniclastics of the Lower Jurassic-Talkeetna Formation are considered the basement complex for practically all of the Copper River Basin exploration area.

\section{Southwest Wrangell Mountains}

A composite section of $31,000^{\prime}+$ of Permo-Pennsylvanian through Quaternary rocks are present (Fig. 4) on the east side of the basin. Only about 6,300' of Upper Jurassic, Lower Cretaceous, and (?) Tertiary sediments are present. The Middle Jurassic rocks are not anticipated in the eastern portion of the basin and the presence of Upper Jurassic sediments is speculative. From 375' to 5,700'+ of Upper Triassic shales and limestones are also present on the outcrop, but are not believed present in the subsurface.

\section{Upper Chitina Valley}

In the McCarthy Area - southern Wrangell Mountains, the composite section of Permo-Pennsylvanian through Quaternary sediments is about 47,500'+ in thickness (Fig. 5). The lower Jurassic - Tertiary sequence is about $13,800^{\prime}$ thick. An additional 4,300' of Triassic carbonates and shales present in this area as in the southwest Wrangell Mountains are not anticipated in the Copper River Basin.

The primary objective horizons are the Nelchina and Naknek Formations (Encls. 1 and 2), and the Tuxedni Formation in the western portion of the basin (Encl. 3). Secondary objectives are the Lower Cretaceous-Kennicott Formation and coeval rocks and the Upper Cretaceous-Matanuska sands and coeval rocks (Encl. 3). 


\section{Skolai Group, Mankomen Group and Coeval Sediments}

Permo-Pennsylvanian rocks completely encircle the basin (Powell, 1975, Encl. 1). This sequence consists of volcanic flows, volcaniclastics, and marine sedimentary clastics and carbonates and have been subjected to various degrees of metamorphism. At different places many authors in the past have described all or parts of this lithologic sequence under different formational names and assigned them to the carboniferous period (either Mississippian or Pennsylvanian ages) and in some areas as Permian Age.

In the eastern and southern Wrangell Mountains, Smith and McKevett (1970), named the widespread marine sequence the Skolai Group in which two formations were defined (Encl. 3). The Station Creek Formation (lower part) up to 6,000' thick, contains two members: a lower volcanic unit of basalt and basaltic andesite flows with minor volcaniclastics up to $4,000^{\prime}$ thick, and an upper volcaniclastic unit, up to 2,000' thick, with a few intercalated lava flows, of (?) Permian age. The base of the formation is concealed. The gradionally overlying Hazen Creek Formation, up to $900^{\prime}$ thick with an erosional top, is composed of thin bedded shale, siltstone sandstone conglomerate, impure limestone, and chert. Locally this member contains the Golden Horn Limestone Lentil, up to $800^{\prime}$ thick, composed of bioclastic limestone. The formation is of Permian Age and unconformably underlies Middle and Late Jurassic rocks with slight angular discordance, or may be overlain with strong angular unconformity by the Tertiary-Frederika Formation or Wrangell Lava (Ibid, Mackevett, 1970 , 1970a, 1971).

Studies in the eastern Alaska Range-northern Wrangell Mountains by Richter and Jones (1973), Richter and Dutro (1975), and Richter (1976), have determined the sequence to range in age from Middle Pennsylvanian to lower Upper Permian and that the Tetelna Volcanics (probably coeval in part with the volcanic flows of the Station Creek Formation) of Pennsylvanian Age is interpreted to represent the development of a volcanic island arc directly on oceanic crust. The Mankomen Formation (Mendenhall, 1905) which is the upper part of the sequence has been elevated to group status composed of two formations by Richter and Dutro (1975). The basal Slana Spur Formation is about 4,500' thick and conformably overlies the Tetelna volcanics. This formation is composed of volcaniclastics, similar and probably equivalent in part to the upper member of the Station Creek Formation. The Eagle Creek Formation at the top of the group is composed of $2,950^{\prime}$ (may exceed $5,000^{\prime} \pm$ ) of massive nonvolcanic marine limestones and argillites and shales of upper Lower and lower Upper Permian age and is equivalent in part to the Hazen Creek Formation. The formation is unconformably overlain by the Nikolai Greenstone of Middle and (or) Upper Triasic Age. The Slana Spur Formation is interpreted to represent the waning stages of the volcanic arc (Ibid).

In the Talkeetna Mountains on the west side of the basin Csejtey (1976) describes a dominantly marine sequence of tightly folded and complexly faulted metavolcanigenic rocks over 16,400' thick (base not exposed) which consists of metamorphosed basaltic to andesitic flows, metavolcaniclastic rocks, and subordinate mudstones, phyllites and thick-bedded to massive bioclastic marbles. The sequence ranges in age from (?) Pennsylvanian to Lower Permian and are interpreted to be the southwest continuation of the volcanic are assemblages of the eastern Alaska Range. 
A similar sequence (undated) of metavolcanogenic rocks are reported by Smith (1974) along south flank of the Alaska Range (north flank of basin). Volcanic and volcaniclastics are described in the Upper Chulitna district (Clark and others, 1972), and in the central and eastern Alaska Range by Mendehall (1905) and Bond (1973). Metamorphosed volcanic and volcaniclastics of Permo-Pennsylvanian age are mapped along the northside of the Border Range fault in the Chugach Mountains (Mackevett and Plajkex, 1971).

\section{Source Rock Information}

Two samples were taken from source rock analysis from the black shales of the Mankomen Group-Eagle Creek Formation along the south flank of the Alaska Range (Encl. 13, photos No. 7I-72, and Sections Nos. 33 and 35, Powell, 1975). Fair to good gas generating source rocks were analyzed in an advance stage of diagenesis by elemental analysis (Harwood, 1975).

\section{TRTASSIC} LOWER TRIASSIC

\section{Unnamed Beds}

The only occurrence of Lower Triassic fossils in the region is reported from a limestone bed near the top of a volcaniclastic sequence in the Upper Chulitna district located in the northwest part of the region (Clark and others, 1972). Thickness is unknown.

\section{MIDDLE TRIASSIC}

\section{Unnamed Beds}

A 700' sequence of limestone, calcareous siltstone, sandstone, argillite and pillow basalts are described as probable Middle and Upper Triassic in the Upper Chulitna District (Ibid).

\section{"Daonella Beds"}

A thin-bedded unit $0-200^{\prime}$ thick of siltstone, shale, minor limestone and chert, carbonaceous in part of local distribution is reported in the eastern Wrangell MountainsMcCarthy B-4 and C-4 Quadrangles (Mackevett, 1970, 1970a) and by Richter and Jones (1973) in the northeast Wrangell Mountains. They unconformably overlie the Permian sediments and are overlain conformably by the Nikolai Greenstone (Encl. 3).

\section{MIDDLE AND (OR) UPPER TRIASSIC}

\section{Nikolai Greenstone}

The Nikolai greenstone is widely distributed throughout the Wrangell Mountains area (Encl. 3, Photos 96-99, 117) and around the northern and northwest part of the region (see Encl. 1, Powell, 1975). The formation consists of a thick 
sequence of altered basaltic lavas, olive grey to dark grey and weathers locally to reddish or reddish brown, coarse textured and commonly amygdaloidal and porphyritic. A basal conglomerate up to 200' thick, composed of clasts from subjacent formations is reported in the Wrangell Mountains (Mackevett, 1970, Moffit and Mertie, 1923, Moffit, 1938). The sequence forms rugged topography and is commonly 3,000$7,000^{\prime}$ thick, attaining a maximum thickness of $13,000^{\prime}$ in the MacCarthy B-4 Quadrangle (Mackevett, 1970). The formation is almost entirely of continental origin (flood basalts) in the eastern part of the region (Ibid, Richter and Jones, 1973). Pillow lavas are reported in the southwest Wrangelis (Encl. 3 and Moffit and Mertie, 1923, Moffit, 1938).

Around the north and northwest part of the region many pillow lava zones are reported from the Amphitheater Group (at least coeval in part with Nikolai greenstone) by Smith $(1974)$.

The volcanic sequence is not mapped or reported around the southern margin of the region or in the eastern Talkeetna Mountains.

\section{UPPER TRIASSIC}

\section{Chitistone and Nizina Limestones}

The Chitistone Limestone is almost entirely restricted to the Wrangell Mountains region, where it ranges in thickness from 75't to 2,300'. The formation disconformably overlies the Nikolai Greenstone and has a gradational contact with the overlying Nizina Limestone. It consists of thin to massive beds of light to medium and some darker grey limestones, minor chert and some dolomite primarily in lower $300^{\prime}$ of section (Encl. 3, Mackevett, 1970a, 1971). The sequence weathers shades of grey to light or yellow-brown. The formation form bold cliffs and in places contain caves and solution cavities. Contacts between the Chitistone and Nizina Limestones transgress time boundaries (Armstrong, Mackevett and Silberling, 1969). Of interest to the mining industry is that the fractured and brecciated dolomites near the base of the section is the host rock for the rich copper ores taken from the Kennecott mines near McCarthy, Alaska (photos 90-99).

The Nizina Limestone, distributed as the underlying formation, $x$ anges in thickness from $350^{\prime}$ to $1,250^{\prime} \pm$ and consists of dark greenish-grey limestones, weather $\bar{s}$ shade of brown, contains subordinate chert nodules and lenses and is thin-bedded. The contact between the Nizina Limestone and McCarthy Formation also transgresses time boundaries (Ibid).

Fossils characteristics of the Chitistone and Nizina Limestones have been found in the Clearwater Mountains region (northwest flank of the basin). by Smith and Lamphere (1971) and Smith and Turner (1973). These faunas were found in a discontinuous limestone lens, intermixed with metabasalts and thin volcaniclastics near the top of a thick volcanic flow sequence mapped as Nikolai Greenstone (near T20S, R4E, FM) . Massive-bedded limestones in the eastern Alaska Range (Nebesna Quadrangle) are considered equivalent to the Chitistone Limestone (Richter, 1976). 


\section{Depositional History and Environments}

The Chitistone and Nizina Limestones have been studied in fair detail along the southern flank of the Wrangell Mountains by Armstrong, Mackevett, and silberling (1969). They interpret that the carbonates were deposited on a drowning platform (Continental-Nikolai Greenstone) and that the Chitistone was deposited in shallow seas under widespread intertidal, supratidal, shallow-water shelf sedimentation intermixed with periodic shoaling deposition. Deposition of the lower part of the Nizina Formation was interpreted as deeper water grainstones, followed by a progradation of a shallow to shoaling environment over the deeper slope carbonate and finally a rapid drowning of the carbonate shelf at approximately the McCarthy Formation contact. The thin-bedded grey to black carbonaceous shales, bedded chert with abundant radiolarians and sponge spicules, and impure limestones are interpreted as deeper water sediments.

A possible reefal buildup was reported in the southwest Wrangells in the Nizina Limestone (Shaw, 1960). This was not field checked during the 1974 field season primarily because of a lodging reservation bust in the vicinity due partly to pipeline construction. Enclosure No. 3 shows a facies relationship of the formation(s) progressively becoming dominantly shale and the entire upper Triassic sequence ultimately eroded. It is doubtful that the carbonate facies is present in the subsurface?

UPPER TRIASSIC - LOWER JURASSIC (?)

\section{McCarthy Formation (Lower Member)}

The lower member of the McCarthy Formation ranges from about $430^{\prime}$ to $1,200^{\prime}$ in thickness and is present only in the Wrangell Mountains Area (Encl. 3; and Encl. 1, Powell, 1975). The unit consists of thin bedded dark grey to black, carbonaceous and calcareous shales, impure limestones and cherts which generally weathers to shades of brown. This unit conformably overlies the Nizina Limestone and gradationally underlies the upper member of the formation. Based on fossil data (Armstrong and other, 1969) the contact transgresses time boundaries. For additional details see Mackevett, 1970, 1970a, b, c, 1971 and 1972).

\section{Age and Environment of Deposition}

It is intexpreted by Armstrong and others (1969) that rapid drowning of the Nizina carbonate platform occurred at the contact with the McCarthy Formation and that deep water to starved basin sedimentation is represented by the lower member.

Fossils of Late Triassic age (late Norian) stage have been found in the lower $400^{\prime}$ of section (Mackevett, 1971) but nothing diagnostic in the overlying beds until Lower Jurassic faunas are found in the upper member. In the Clearwater Mountains, fossils characteristic of the lower McCarthy Formation were found in a limestone lens intermixed with metavolcanics (Smith and Turner, 1973). Thin bedded limestones mapped in the Nebesna Quadrangle are considered equivalent to the lower member of the McCarthy Formation (Richter, 1976). 


\section{Source Rock Information}

One sample from an argillaceous bed in the Triassic limestone unit (believed to be from the lower McCarthy Formation) in the eastern Alaska Range was analyzed as nongenerating (Miers and Taylor, 1974).

\section{JURASSIC}

\section{LOWER JURASSIC}

\section{Talkeetna Formation and Coeval Rocks}

The Talkeetna Formation is well exposed on the west side, northwest, and south flanks of the basin; and has been drilled in the subsurface over much of the basin. Coeval rocks - McCarthy and Lubbe Creek Formations - are exposed in the Wrangell Mountains (Encl. 1, Powell, 1975).

The Talkeetna Formation is about $6,000^{\prime}-8,000^{\prime}$ thick and consists of an upper volcanic clastic unit in the upper part, flows and pyroclastics in the middle portions and volcaniclastics (sandstones and argillites) in the lower portion (Imlay and Detterman, 1973). The very top of the sequence was examined on Sheep Mountain, Mouse Creek, Chitna Creek, and Little Oshetna River (see Sections 1, 8, 9 and 24, Powel1, 1975, Appendix; and photos 2, 13, 30, 33, Encl. 14, Appendix). The lithology consisted of varicolored shale, siltstone, very fine to coarse grained sandstones and pebble to cobble conglomerate with much volcanic and igneous material. Marine fossils and traces of fossil wood were found in the sandstones and siltstones. The rocks weather (and/or have been altered) to yellow or shades of reddish brown color and, in many places, form rugged relief.

\section{Contact Relationships}

The formation is unconformably overlain progressively to the north by Middle and Upper Jurassic sediments (Photo 12) and ultimately to west and north by Tertiary continental sediments or volcanics and Quaternary deposits. Upper Cretaceous-Matanuska Formation overlies the Talkeetna Formation with strong angular discordance on sheep Mountain (Photos 58, 59, 63). Farther south, along the front of the Chugach Mountains, Lower Cretaceous (Albian Age)-Matanuska sediments onlap the Lower Jurasic rocks with angular discordance. The base of the sequence is not exposed.

\section{Environment of Deposition and Reservoir Quality}

The Talkeetna Formation was deposited primarily under marine conditions and in a volcanic arc environment (Imlay and Detterman, 1973). The formation was intruded, deformed and altered near the end of the period and is considered the basement complex for essentially the entire basin.

The formation was not examined in detail but due to alteration and an average porosity of $5.3 \%$ and permeability of about $5 \mathrm{mds}$. from upper beds, the sequence is not considered a reservoir objective. No samples were submitted for source rock analysis. 
Listed below are the porosity and permeability data on the sandstone samples submitted to Amoco Research Lab and gathered from other sources.

\section{TALKEETNA FORMATION}

\begin{tabular}{|c|c|c|c|c|}
\hline $\begin{array}{l}\text { Sample } \\
\text { Number } \\
\end{array}$ & Member & Location & $\begin{array}{c}\text { Porosity } \\
\frac{\%}{2}\end{array}$ & $\begin{array}{l}\text { Permeability } \\
\text { Mds. }\end{array}$ \\
\hline CR-9l.L & Top & $\begin{array}{l}\text { NE Sec. 3, T } 20 \mathrm{~N} \\
\text { RIIE, SM }\end{array}$ & 3.5 & 11.9 \\
\hline B-194 & Top & Horn Mountain & 4.2 & 2.0 \\
\hline \multirow[t]{2}{*}{$B-211$} & ? TOP & $\begin{array}{l}\text { SW Sec. } 9, \text { T22N } \\
\text { R12E, SM }\end{array}$ & 8.2 & 1.0 \\
\hline & & & 15.9 & 14.9 \\
\hline
\end{tabular}

Porosity Range 3.5-8.2\% average 5.3\%

Permeability Range 1.0-11.9 mas. average $4.96 \mathrm{mds}$.

Samples with prefix of B from Borax, and others, 1958.

\section{Coeval Sediments}

Contemporaneously with the volcanic arc sedimentation to the west, are the deeper to shallow marine deposits of the upper member of the McCarthy and Lubbe Creek Formations in the Wrangell Mountains (Encl. 3).

\section{McCarthy Formation (Upper Member)}

The upper member of the McCarthy Formation ranges up to 2,500' in thickness and consists of interbedded, siliceous, calcareous siltstones, shales and limestones with some layered chert and minor spiculites (Encl. 3, and section No. 58 in Appendix, Powell, 1975; Photos 101, 103, 104, 105, 116).

The contact between the lower and upper members is gradational and also gradational with overlying Lubbe Creek Formation. Where Lubbe Creek Formation is eroded a disconformable contact with the Nizina Mountain or Root Glacier Formation is present. Locally the formation is overlain with angular unconformity by Lower Cretaceous-Kennicott Formation (Photo 116).

\section{Age and Environment of Deposition}

Practically the entire member has been dated as Lower Jurassic, only the very basal part could possibly range into the Upper Triassic. The sequence was believed deposited in relatively deep water or as reported by Mackevett (1971) in "a rather quiet sea." For additional details see Mackevett $(1970,1970 a, b, c, 1971$, and 1972).

\section{Lubbe Creek Formation}

This formation consists of dark grey, hard, siliceous limestones, limy siltstones (in part shaly), some chert, and 
coquina and spiculites beds; and ranges from 0 to $300^{\prime}$ in thickness (Encl. 3, photos 101 and 104, Section No. 58, Powell, 1975).

The Lubbe Creek Formation conformably overlies the upper member of the McCarthy Formation. The upper contact is separated from the Nizina Mountain or overlying Root Glacier Formations by a disconformity.

\section{Age and Environment of Deposition}

The formation has been dated as Lower Jurassic and interpreted as nearshore marine deposits that have been subjected to wave action (Mackevett, 1971; also see Mackevett, $1969,1970,1970 a, b, c$, and 1972).

\section{Reservoir Qualities and Source Rocks}

No reservoir quality rocks were noted in either the McCarthy or Lubbe Creek Formations. A siltstone sample from the Lubbe Creek Formation indicated a poor oil source in peak gas and past peak oil stages of diagenesis. Two samples of shale and siltstones from the upper member of the McCarthy Formation analyzed nonsource to poor oil source at same stages of diagenesis as the Lubbe Creek Formation. Visual analysis indicates peak oil or early past peak (Encl. 12).

\section{Other Lower Jurassic Rocks}

An ophilotic sequence of serpentinite, gabbro, basalt and bedded chert are reported from the northwest part of the region - Upper Chulitna district and has been interpreted as oceanic crust at a suture zone (Clark and others, 1972).

\section{MIDDLE JURASSIC}

Tuxedni and Nizina Mountain Formations

The Tuxedni Formation is exposed only in the eastern Talkeetna Mountains and is composed of sandstone, pebbly to conglomeratic sandstone, shale, mudstone and.siltstone almost entirely of marine origin attaining an estimated maximum thickness by Grantz (1953) of 2,400't. Our limited work in the area indicated a composited section of about $1,625^{\prime}$ and that the formation, based on fossil control, is divisible into two members.

\section{Lower Member}

The lower part of the Tuxedni Formation is $700^{\prime}$ thick at Mouse Creek (Encl. 5, and Section No. 8, Powell, 1975, appendix) and consists mainly of olive grey sandstone, which weathers brownish grey, is massive and cliff forming. The sandstones are fine grained, pebbly to an occasional conglomerate lens, with siltstone in the lower part, fossiliferous and have poor reservoir qualities averaging less than 5\% porosity and about $0.1 \mathrm{mds}$. for permeability. Similar quality sandstones are present at Caribou Creek (No. 7, Powell, 1975, 
Appendix) and Chitna Creek Sections (No. 9, Ibid, photos, $6,25,31,32$ and 33). Low angle cross bedding (Photo 34) and scour with coquina fill (Photo 35) are believed evidence of nearshore, intertidal sedimentation.

of particular interest are the quartz-rich sandstones located along the north side of Horn Mountain (Photo No. 29). These friable, yellow brown to orange-red sandstones have good reservoir qualities ranging up to $18 \%$ porosity and $87 \mathrm{mds}$. permeability. These sandstones are believed present and a drilling objective in western part of the basin (see Encl. 3 for facies interpretation).

\section{Contacts and Age Determinations}

The lower member unconformably overlies the Talkeetna Formation and is unconformably overlain by the upper part of the formation. A Bajocian Age-lower Middle Jurassic has been determined from megafossil data (Grantz, 1953 and Derby, 1975).

\section{Upper Member}

The upper part of the formation is $925^{\prime}$ thick on Cardioceros Creek (Section No. 26, Powell, 1975) and is predominantly sandstone, very fine to medium grained, weathers brownish red to yellow brown, fossiliferous, with some black shaly calcareous siltstones interbedded. This unit has fair porosity up to about $15 \%$ but only $0.1 \mathrm{mds}$ permeability. More black sandy mudstone and shale with pebbly sandstone is noted on the Little Oshetna River (Section No. 24, Powell, 1975; and photos No. 7 and 12). Thin coaly beds indicate continental or coastal marsh influence in this area.

\section{Contacts and Age Determinations}

The upper part is of upper Middle Jurassic age (Derby and Scott, 1974, Grantz, 1953, Imlay and Detterman, 1973) and unconformably overlies the lower unit or the Talkeetna Formation to the north (see Encl. 3 and 5).

\section{Nizina Mountain Formation}

The Nizina Mountain Formation is present only in the McCarthy area of the Wrangell Mountains and is composed of thin bedded, hard, dark grey to black shales, siltstones and sandstone which weather a very characteristic reddish brown (Encl. 3, photos 100, 101 and 102; see Lubbe Creek section No. 58, Powell, 1975, Appendix). The formation ranges up to $1,350^{\prime}$ in thickness and disconformably overlies the Lubbe Creek Formation or the upper member of the McCarthy Formation when the Lubbe Creek Formation is absent. The upper contact is a strong erosional surface disconformably overlain by the Root Glacier Formation or with strong angular unconformity by post Jurassic beds. For additional details see Mackevett (1969, 1970a, 1970b, and 1971).

\section{Age and Environment}

The age of the sequence was originally considered as upper Middle Jurassic-Bathonian Stage and (?) lower Upper 
Jurassic-Callovian Stage (Ibid) but has since been assigned to the Bathonian stage (Imlay and Detterman, 1973) and is equivalent to the upper part of the Tuxedni Formation in the Talkeetna Mountains. Mackevett (1971) interprets a moderately deep marine environment of deposition.

\section{Source Rocks and Reservoir Qualities}

The Nizina Mountain has very good oil generating capabilities at past peak stage of maturity (Encl. No. 11, Harwood, 1975) as determined from one sample. Three samples of the Tuxedni Formation from the subsurface and Talkeetna Mountains area indicate a nonsource to very good wet gas source rocks in a pre- to early generation stage (Ibid, Byington, 1973).

The Nizina Mountain Formation from limited visual determination is not of reservoir quality and is probably not present in the eastern portion of the basin. Coeval rocks of Bathonian age in the Talkeetna Mountains showed porosity values ranging from $3.2 \%$ to $14.9 \%$ averaging $8 \%$, and permeability range of .0 to $131 \mathrm{mds.,} \mathrm{averaging} \mathrm{about} 22 \mathrm{mds}$. The average is weighted by a single sample and an average of less than . I mas. is more likely. The lower member of the Tuxedni Formation (Bajocian Age) show a porosity range of $4.5 \%$ to 18. 3\% averaging about $10.5 \%$ and permeability of $0-87 \mathrm{mds}$., avergaging $12.6 \mathrm{mds}$. The lower Tuxedni sandstones, particularly the friable sandstones found in the north Horn Mountain area are considered prospective in the western part of the basin. Additional samples were collected in 1976 and submitted to the Research Center for analysis.

Listed below are the porosity and permeability data on the sandstone samples submitted to Amoco Research Lab, Core Lab, and those gathered from other sources.

\section{TUXEDNI FORMATION}

Upper Member (Bathonian Age)

Sample
Number
60-Sh-41

60-Sh-4I
$60-S h-41$
L-2lb
CR-30L
CR-3lL

\section{Location}

\section{Cardioceras Creek}

Section 1, T23N, R9E,

Section 6, T23N, RI0E, Sections $31,32, \mathrm{~T} 24 \mathrm{~N}$, RIIE, SM "

SE Sec. 3l, T24N, RIOE, SM NE Sec. 17, T24N, RlOE, SM NE Sec. 17, T24N, RIOE, SM

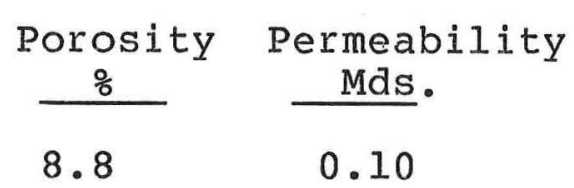

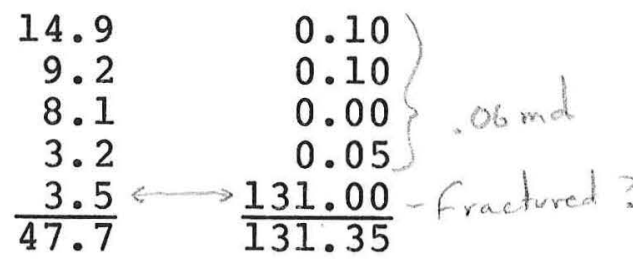

Porosity Range 3.2-14.9\% average $7.95 \%$

Permeability Range 0-131 mds. average 21.89 mds. (weighted by one sample) 
Lower Member (Bajocian A'ge)

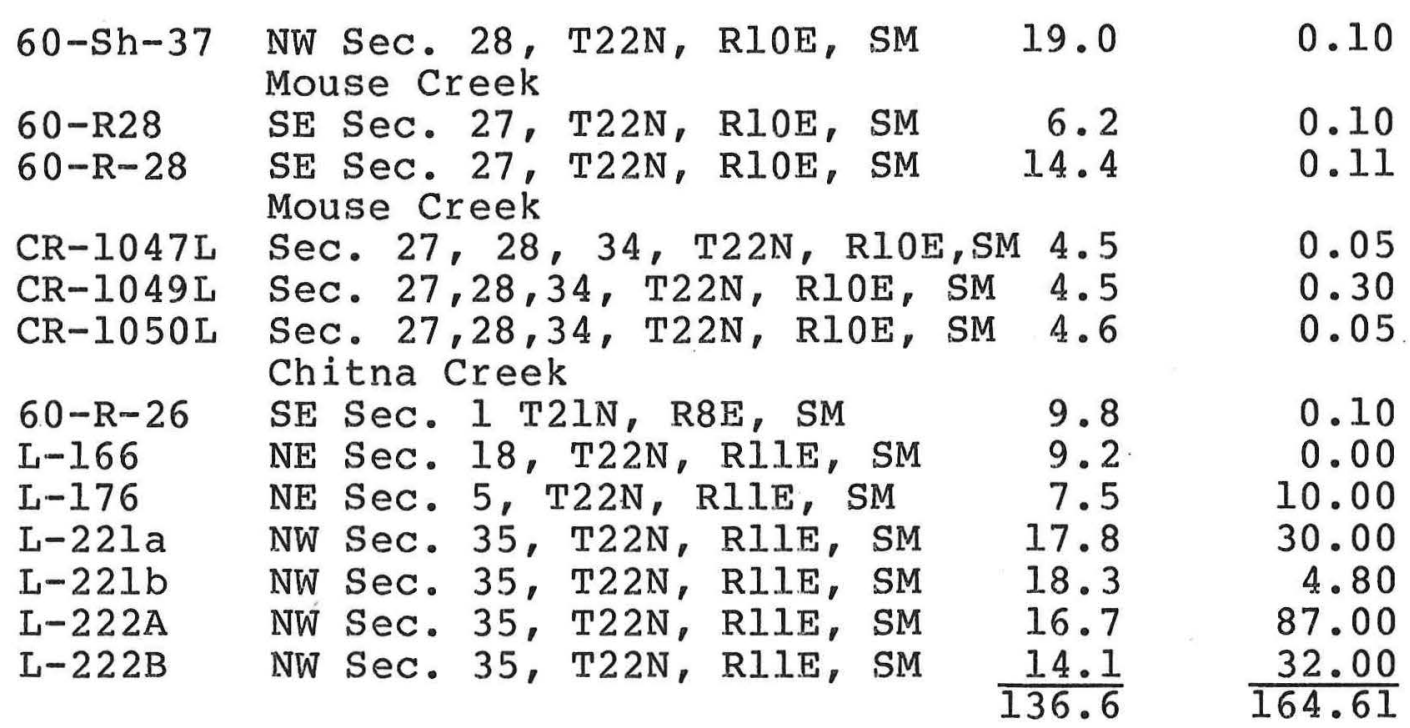

Porosity Range 4.5-18.3\% average 10.51\%

Permeability Range 0-87 mds. average 12.66

Samples with prefixes L are from Borax; and others, 1958

UPPER JURASSIC

Chinitna Formation (Callovian Age)

Outcrops of the Chinitna Formation are found only on the eastern flank of the Talkeetna Mountains (Encl. 5, Encl. 1 of Powell, 1975) and in the subsurface of the western Copper River Basin (Encls. 3 and 6). The formations consist of marine shales, claystones, limestone lentils and concretions, siltstones, sandstones and conglomerates with marine fossilsbelemnites, pelecypods and ammonites. The sequence is olive grey to greenish grey and weathers yellowish, rusty or other shades of brown. Where complete exposures have been examined the thickness of the unit varies from 640' to a maximum of 790' (Encl. 5).

The Chinitna Formation disconformably overlies the lower Tuxedni member to the south and the upper member to the north with no apparent discordance. The Naknek unconformably overlies and completely overlaps the Chinitna Formation in the northeastern part of the area. No Callovian age rocks are present in the Wrangell Mountains, however, an unconformity is strongly developed (Encl. 3) where Chinitna age rocks would normally be located.

\section{Environment of Deposition}

At the Little Oshetna River Section No. 24 (Encl. 5, photos 7 and 11; Powell, 1975, Appendix) a basal fossiliferous, pebble-cobble conglomerate about 165' thick, with cut and fill structures, and some graded bed is present. This unit became more sandy and silty toward the top and facies laterally into siltstones, shale and overlying claystones and is thought to represent a nearshore subaquous distributary system. To the southeast, about 10 miles, on Lower Bubb Creek Section No. 17 (Powell, 1975; Photos 26 and 27) are thin lenses of sandstones, grey to brown, fine to coarse grained, pebbly 
to conglomerate beds which locally facies to shaly sandstones and sandy shales. The unit is abundantly fossiliferous, has many scour and fill structures, and may be equivalent to the basal conglomerate zone to the northwest. This unit is interpreted as nearshore-restricted bay or low energy intertidal zone. An east-west facies interpretation is shown on Enclosure 3.

In the southern portion of the area the formation consists of shales and more uniform thinly interbedded sequence of shales, siltstones, sandstones, limestone lentils, and concretions which are fossiliferous in part; and is believed to represent somewhat deeper water (Encl. 5; Photos 31, 32 and 36 of Chitna Creek Area).

\section{Source Rocks and Reservoir Qualities}

Based on three samples the Chinitna Formation is a nonsource (two samples) to a fair oil source at pregeneration stage of diagenesis (Encl. No. 10; Harwood, 1975). At the Lower Bubb Creek Section, two sandstone samples averaged 9\% porosity and $1.3 \mathrm{mds}$. permeability. Could become prospective in the western part of the basin if sandstones are subjected to higher energy.

Listed below are the porosity and permeability values for two sandstone samples collected by Union Oil Co. (Borax and others, 1958) from the Lower Bubb Creek Section No. 17 Appendix).

\section{CHINITNA FORMATION}

Sample

Number

L-173

L-173A

Location

Lower Bubb Creek SW Sec. 22, T23N, RIIE, SM

Lower Bubb Creek SW Sec. 22, T23N, RIIE, SM

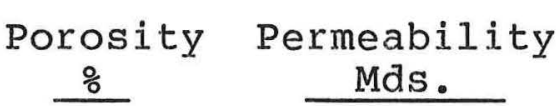

9.1

2.6

9.0

0

Porosity Range 9.0-9.1\% average 9.05\%

Permeability Range 0-2.6 average $1.3 \mathrm{mds}$.

Naknek Formation and Coeval Rocks (Oxfordian to Early Portlandian Age)

The Naknek Formation outcrops extensively along the eastern flank of the Talkeetna Mountains (Nelchina Area) and are present in the western and possibly eastern portions of the Copper River Basin (Encl. 2; Encl. 1 of Powel1, 1975). Coeval sediments, the Kotsina Conglomerate and Root Glacier Formation are present in the Wrangell Mountains; the "Nuzotin Mountains" sequence in the eastern Alaska Range; and two unnamed sequences in the northwest portion of the region. Upper Jurasic rocks are absent along the northern front of the Chugach Mountains and southern part of the central Alaska Range. 
The formation disconformably or with angular discordance overlie older Jurassic to Triassic sediments and in turn is unconformably overlain by Lower Cretaceous, Upper Cretaceous and Tertiary deposits (Encls. 3 and 5).

\section{Naknek Age Sand Trends and Facies}

Cross Sections $\mathrm{H}-\mathrm{H}^{\prime}, \mathrm{I}-\mathrm{I}^{\prime}, \mathrm{J}-\mathrm{J}^{\prime}$ (Encls. 3, 5, and 6) measured sections (Appendix, Powell, 1975) and well data provide the control for the interpreted facies and sand trend map (Encl. 2) of the Naknek Formation in the Copper River Basin. The Naknek Formation appears more prospective in the western portion of the basin than in the eastern part primarily because the control data gives more assurance that the formation is present in the subsurface.

\section{Western Basin Area}

The Naknek Formation is mainly of marine origin and ranges in thickness from $0^{\prime}$ to a composited maximum of about $2,563^{\prime} \pm$ (Encl. 3). The formation is divided into three members: a basal conglomerate (equivalent timewise to the Chisik Conglomerate of the cook Inlet region), middle shale and siltstone unit, and an upper sandstone unit. The thickness of the units vary considerably about the area, and it is concluded that the members do not represent blanket deposits, but are changing facies which become more marine southward. Facies and trends of the upper and lower members, along with a diagrammatic sketch model of the depositional facies are shown on Enclosure 2. Stratigraphic cross-section I-I' shows the correlation of the Naknek Formation along the east flank of the Talkeetna Mountains (Encl. 5) and Section $\mathrm{H}-\mathrm{H}^{\prime}$ (Encl. 3) ties the Talkeetna Mountains to the Wrangell Mountains.

A generalized description of the members of the Naknek Formation is given below. For more details see Enclosure 5 and the stratigraphic sections in the appendix of Denver Division Report 154 (Powell, 1975).

\section{Basal Conglomerate (Chisik) Member}

The basal unit is grey to dark grey to brownish grey, pebble to cobble to boulder conglomerates of volcanic and granitic material in a siltstone to silty sandstone matrix. The unit has a dark and massive appearance. The conglomerates vary in thickness and at the Little Oshetna River section No. 24 (Encl. 5, photos 7, 8,9 and 10) is about $825^{\prime}$ thick with some boulders exceeding $8^{\prime}$ in diameter. To the west it is estimated that the conglomerate member is about 1,700 ' thick. The clasts are locally derived, angular to wellrounded and contain a large amount of Talkeetna volcanic rocks and somewhat less granitic rocks.

\section{Environment of Deposition and Reservoir Qualities}

The basal unit was deposited in a nearshore-deltaic environment. Continental deposits may be present in the thick conglomerate facies. The facies change to sandstone is not a uniform trend, as the conglomerates may abruptly 
facie to a siltstone and shale facies rather than to a sandstone. If the debris is deposited from steep sided mountains into the sea an abrupt facies change from conglomerate to siltstone and thin sandstones to shale may occur. There is no cleanup by wave action and poor reservoirs. When sediments are carried into the system along shallower gradients such as distributaries into nearshore conditions there is a better chance to develop sand facies and better reservoirs. Steep sided sources appear more prevalent in the lower Naknek (Encl. 3).

Porosity in the lower unit ranges from $3.2 \%$ to $16.4 \%$ and average about $10 \%$; whereas, the permeability ranges from 0-3.15 mds. and averages about $1 \mathrm{mds}$.

\section{Middle Shale and Siltstone Member}

The middle unit is about $1,000^{\prime}$ thick and consists of dark grey to black, blocky shale and siltstone with limestone concretions. This sequence was deposited in deeper water and has no reservoir beds (Photo 39).

\section{Upper Sandstone Member}

The upper member is composed of grey, very fine to medium grained sandstones, calcareous in part, slightly shaly and with low angle cross-bedding (Photos 49-50). Conglomerates interbedded or lensing with sandstones and shales are common (Photos $14-18,22,28$ ). The unit shows channel-like lenses of conglomerates and sandstones (Photo 16), fining upward (photo 23), intraformational unconformities (photos 21-22, 24), probable recent slide structures (Photos 17-18), highly fossiliferous locally (Photos 51-54); and is variable in thickness. At Limestone Gulch Section 10 (Encl. 5) the upper sandstone unit is about $738^{\prime}$ thick.

\section{Environment of Deposition and Reservoir Qualities}

The upper sandstone member was deposited under nearshore, possibly shoreline and deltaic conditions. The unit has fair to good reservoir qualities with porosities ranging from $3.6 \%$ to $21.7 \%$, averaging about $12 \%$ and permeabilities varying from 0 to $196 \mathrm{mds}$, averaging about $14 \mathrm{mds}$.

Listed below are the porosity and permeability values for the sandstone samples submitted to Amoco Research Lab, Core Lab, and those gathered from other sources.

\section{NAKNEK FORMATION}

\section{Upper Sandstone Member}

Sample Number

$60-\mathrm{R}-27$

\section{Location}

Limestone Gulch

Sec. 5, T22N, RIOE, and

Secs. $31,32, \mathrm{~T} 23 \mathrm{~N}, \mathrm{R} 10 \mathrm{E}, \mathrm{SM}$

Limestone Gulch

Sec.5, T22N, RI0E, and

Secs. 31, 32, T23N, RIOE, SM
Porosity Permeability

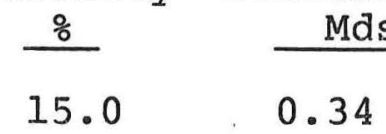

20.7

30.00 
Sample
Number

CR-113L

$60-\mathrm{Sh}-7$

$60-\mathrm{Sh}-7$

$60-\mathrm{Sh}-9$

$60-\mathrm{Sh}-9$

CR-63-L

CR-64-L

CR-60-L

$60-\mathrm{Sh}-11$

$60-\mathrm{Sh}-16$

$60-S h-28$

$60-S h-28$

$60-\mathrm{Sh}-28$

CR-128-I

$\mathrm{B}-223$

$\mathrm{L}-204$

CR-104L

$\mathrm{L}-201$

$\mathrm{L}-202$

L-203

W-150

\section{Location}

Billy Creek No. I (10a)

Secs. 5 \& 6 T22N, Rl0E, SM

Little Nelchina River

SW Sec. 4, T23N, RI2E, SM

Little Nelchina River

SW Sec. 4, T23N, RI2E, SM

North Little Nelchina River

NW Sec. 8, T23N, RI2E, SM

North Little Nelchina River

NW Sec. 8, T23N, RI2E, SM

North Little Nelchina River

NW Sec. 8, T23N, RI2E, SM

North Little Nelchina River

Lower Flat Creek

NW Sec. 18 , T23N, R12E, SM

Lower Flat Creek

SE Sec. 18, T23N, RI2E, SM

Lower Flat Creek

NW Sec. 31, T23N, RI2E, SM

Lower Flat Creek

NW Sec. 34, T23N, RI2E, SM

Lower Flat Creek

NW Sec. 34, T23N, Rl2E, SM

Lower Flat creek

NW Sec. 34, T23N, RI2E, SM

White Hill

SE Sec. 2, T23N, RIIE, SM

$\mathrm{SE}$ Sec. 4, T23N, R12E, SM

SE Sec. 30, T23N, RlOE, SM

SE Sec. 3, T23N, RI0E, SM

Strat section $\mathrm{H}$

SE Sec. 30, T23N, RI0E, SM

Strat section $\mathrm{H}$

SE Sec. 30, T23N, RI0E, SM

Strat Section $\mathrm{H}$

SE Sec. 30, T23N, RI0E, SM

Upper Flume Creek

$\begin{array}{rc}\begin{array}{c}\text { Porosity } \\ \frac{\%}{9}\end{array} & \begin{array}{c}\text { Permeability } \\ \text { Mds. }\end{array} \\ 19.9 & 3.80 \\ 21.7 & 14.00 \\ 16.1 & 196.00 \\ 13.9 & 0.34 \\ 6.0 & 2.11 \\ 8.6 & 2.51 \\ 11.3 & .85 \\ 18.9 & 23.00 \\ 6.3 & 0.00\end{array}$

$16.7 \quad 12.00$

$16.7 \quad 0.23$

6.40 .10

$15.5 \quad 3.49$

$3.6 \quad 0.00$

$8.4 \quad 7.10$

$5.6 \quad 0.18$

$11.1 \quad 23.0$

$8.5 \quad 0.4$

$7.4 \quad 1.5$

$5.2 \quad 0.0$

$\overline{273.1} \quad \overline{322.05}$

Porosity Range 3.6-21.7\%, average 11.87\%

Permeability Range 0-196 mas., average 14.00 mas.

Lower Conglomerate - Sandstone Member

$60-R-30$

CR-54L

$B-225$

B-303
NW Sec. 17, T24N, RlOE, SM

SE Sec. 24, T25N, RllE, SM

C/Sec. 11, T25N, R12E, SM
SW Sec. 36, T25N, RIIE, SM

$\begin{array}{rr}16.4 & 0.11 \\ 12.4 & 3.15 \\ 3.2 & 0.00 \\ 7.0 & \frac{1.00}{4.26}\end{array}$

Porosity Range 3.2-16.4\%, average $9.75 \%$

Permeability Range 0-3.15 mds., average $1.06 \mathrm{mds}$.

Samples with prefix B, L and W are from Borax, and others, 1958.

\section{Eastern Basin Area - Wrangell Mountains}

\section{Kotsina Conglomerate}

The Kotsina Conglomerate is present only in the southwest Wrangell Mountains and is composed of dark grey to olive 
grey, pebble-cobble-boulder conglomerates with lenses and interbeds of dark grey, hard shale and sandstones which contain carbonaceous material and plant fragments. The conglomerate clasts are well rounded and are locally derived from subjacent formations, mainly dark altered volcanic formations, Triassic limestones, shales and cherts and with some lighter colored intrusives, sandstones and quartz. The matrix is composed of shaly, silty or sandy material, and the sequence has been intruded by dioritic dikes (Moffit and Mertie, 1923, Grantz and others, 1966).

The formation has a dark, thick bedded to massive appearance, forms rugged topography and has been estimated at 1,500 to $2,500^{\prime}$ thick (Ibid). It unconformably overlies the upper Triassic-volcanics, carbonates and shales, with apparent angular discordance (Encl. 3). The formation is unconformably overlain by the Tertiary Wrangell lava.

\section{Reservoir Qualities, Depositional Environment and Age}

The conglomerates, matrix material and sandstone at the base of the formation is hard and tight. It is only speculative that a conglomerate to sandstone facies occurs in the eastern portion of the basin. The Kotsina Conglomerate could have been deposited under marine or continental (or both ) conditions similar to the massive conglomerates of the Naknek Formation. No identifying faunas have been found in the formation other than from the older clasts. The Kotsina is considered of Upper Triassic-Naknek age because of its stratigraphic position and its interpreted relationship to the unconformable surface developed in the McCarthy area at the base of the Upper Jurassic rocks (Encl. 3).

\section{Root Glacier Formation (Oxfordian-Kimmeridgian Age)}

The Root Glacier Formation is exposed in the southern Wrangell Mountains-McCarthy Area and attains a maximum thickness of about 4,100'+ at the Lubbe Creek Section (Encl. 3, Photos 100-101, Section No. 58, Appendix, Powell, 1975). The formation disconformably overlies the Nizina Mountain Formation and locally the Lubbe Creek Formation, and is unconformably overlain by the Tertiary-Frederika Formation, Wrangell Lava or Quaternarysnow and ice fields.

The formation consists dominantly of hard, black, calcareous, fissile to blocky weathered shales, siltstone and lesser amounts of sandstones, conglomerates and limestone concretions. Two conglomerate zones are present in the upper half of the section. Near the midpoint of the section is a 225' unit with a basal pebble-cobble conglomerates and lenses of sandstones and shales that grades upward into fine the medium grained, brown sandstone and thin interbedded shales and sandstones. An upper conglomerate lentil or tongue, $200^{\prime}$ to 600' \pm in thickness is located near the top of the sequence and is composed of rounded pebbles and cobbles of limestone, siliceous lime-mudstone, greenstone, granitic rocks, shale and some chert in a sandy matrix. The unit is thick bedded and grades upward and laterally into pebbly or coarse grained sandstones (for additional details see MacKevett, 1969, 1970b, 1971 and 1972). The conglomerates may represent tongues such as seen in the Naknek Formation on the western side of the basin and the lower cook Inlet region. 
A local source area is present to the north in the higher parts of the Wrangell Mountains which shedded sediments to the north as well as to the south. A moderately shallow sea is proposed as the depositional environment by Mackevett (1971). Visually the sandstones and conglomerates were considered as having tight to poor porosities.

\section{Eastern Alaska Range}

"Nuzotin Mountain" Sequence (all from Richter, 1976)

"A widespread and thick sequence of predominantly shallow and deep intertonguing marine sedimentary rocks ranging in age from Late Jurasic to Lower Cretaceous is informally referred to as the Nuzotin Mountains sequence" (Richter, 1976).

The sequence probably exceeds 9,600' and is divided into a lower, middle and upper lithologic units.

The lower unit is about 2,900' of dark grey argillites with lesser mudstones, siltstones, greywackes and impure limestones. Southward, over 4,800' of massive beds of shallow water pebble to cobble conglomerates are interbedded with argillites and siltstones which in part is carbonaceous and contains carbonized wood. The sediments were derived from both south (Wrangell area) and north (Yukon area) of the Denali fault. Late Jurassic fossils are abundant.

The middle unit consists of a turbidite deposits of argillites, siltstones and greywacke in graded beds that alternate with massive pebble to cobble conglomerate, greywacke and argillite beds in some parts of the area. The conglomerate clasts were derived from sources both north and south of the Denali fault. The sequence is in facies with the other units and no specific thickness is given other than many thousands of feet of beds. A few Late Jurasic fossils were found.

The upper unit is about 3,500 to $4,900^{\prime}$ thick and consists of graded argillites, greywackes, and grey mudstones which contain fossils of Late Jurassic to Early Cretaceous age. To the south a nonmarine sequence, about 9,600' thick, of thin bedded, carbonaceous sandstones, siltstones and shales with minor grits and conglomerates are correlated to the unit (no fossils found).

Much of the sequence has been strongly folded, thrust faulted, intruded and thermally metamorphosed (for additional data see Berg and others, 1972, Richter and Jones, 1973, Miers and Taylor, 1975, and Richter, 1976).

\section{Northwestern Part of Region}

Several thousand feet of argillite, greywacke and conglomerate are considered of Late Jurassic-Early Cretaceous age in the Upper Chulitna district (Clark and others, 1972).

Conglomerate in the metasediments of the Maclaren metamorphic belt have been dated by fossils as Upper Jurassic and these rocks may be the equivalent of the Nuzotin Mountains sequence (Smith, 1974). 
The source rock evaluation map (Encl. 10, Harwood, 1975) shows the distribution and results collected from the area. Based on four samples the Naknak Formation is a nonsource (three samples) to a poor gas source at pregeneration stage of diagenesis. A tight sandstone on Upper Yacko Creek was tested by Union Oil Co. (Borax and others, 1958) and contained hydrocarbons from methane to at least heptanes, but in such small amounts they were unable to make a quantitative estimates using the mass spectrograph.

The Root Glacier Formation has poor oil generating capabilities (in four samples) at past peak stage of diagenesis, and a poor gas source (in one sample) at peak to early advanced state of maturity.

Not shown on Enclosure 10 are the nine samples from the "Nuzotin Mountains" turbidite sequence (Miers and Taylor, 1974). Six of the samples analyzed as nongenerating, two samples indicated a poor gas capability, and one sample showed a fair wet gas generating capability. All samples were carbonized and in advanced diagenesis.

Additional Naknek samples were collected during July, 1976 and submitted to the Research Lab for source rock evaluations.

\section{CRETACEOUS}

\section{LOWER CRETACEOUS}

Nelchina Formation (Neocomian Age)

Martin (1926) applied the name Nelchina Limestone to the bold cliff-forming, grey limestone beds capping the hills near the headwaters of the Nelchina River (Photos 3738). By common usage, particularly by the petroleum industry, the Nelchina Formation includes three members; the limestone, and the associated underlying and overlying sandstones as described and mapped by Grantz (1953, 1960a, b, \& C, 1961 $a \& b, 1965)$. For purposes of this report the Nelchina Formation terminology will be used.

The Nelchina Formation crops out on the west and east sides of the basin (Encl. 1 and Encl. 1 of Denver Division Report 154) and is present in the subsurface at the Pan American \#1 Moose Creek Unit, Section 4, T4N-R3W, CRM and the Mobil \#1 Salmon Berry Lake Unit, Section 24, T6N-R6W, CRM. The formation unconformably overlies the Upper JurassicNaknek Formation (Photos 37, 40) in the Talkeetna Mountains (Nelchina Area) with no apparent discordance; in the southwestern Wrangell Mountains, overlies with marked unconformity the Triassic-McCarthy and Nizina Limestone and granodiorite intrusive of Upper Jurassic age; and in the Chugach Mountains across the Copper River from Chitina, unconformably overlies the Permo-Pennsylvanian Metamorphosed skolai Group.

The Nelchina Formation is of marine origin and ranges in thickness from $70^{\prime}$ to $1,900^{\prime}$. In the Nelchina Area at the Limestone Gulch Section (Powell, 1975, Encl. 4), the Nelchina is $1,238^{\prime}$ thick consisting of three units, a lower sandstone $520^{\prime}$ thick overlain by $120^{\prime}$ of bioclastic limestone (calcarenite composed mostly of Inoceramus shells), and an upper sandstone $49^{\prime}$ thick. the sandstones are quartzose, arkosic, and poorly cemented to friable. Measured porosities from the better cemented samples vary from 14.8 to $14.8 \%-$ $24.3 \%$, with permeabilities from .34 to 669 mas. The upper 
$700^{\prime}$ of the lower, middle and upper Nelchina Formation have a strong petroleum odor on fresh breaks and possible olivebrown oil stain. The limestone and the upper sandstone units have strong oil odor on fresh breaks and the oil-stained appearance throughout the Nelchina Area and at several localities in the southwest Wrangells. Several fresh samples collected in July, 1976 have been sent to the Research Lab for extract analysis. No initial fluorescence or cut was obtained, but a slight greenish-brown fluorescence remained after. the sample dried. These sands were derived predominantly from a quartz diorite batholith to the west and north which became a source for sediments as early as Middle Jurassic.

A generalized and composited description of the members of the Nelchina Formation is given below. For more details see the stratigraphic sections in the Appendix of Denver Division Report 154 (Powell, 1975).

\section{Lower Sandstone Member}

The lower sandstone unit is light grey to olive grey and green, tan, light brown, yellow brown and brown to black, weathers shade of brown, fine to coarse grained to pebblecobble-boulder conglomerate, medium to massive bedded, quartzose and arkosic, friable, argillaceous to poorly sorted, calcareous, carbonaceous, fossiliferous to coquinoidal beds, and crossbedded, low angle to channel type.

The unit is from $0^{\prime}$ to over $500^{\prime}$ thick and the rocks have fair reservoir qualities averaging about $12 \%$ porosity and 29 mds. permeability. No oil stain or odor was noted other than that reported at Limestone Gulch. The black colored sandstones appear to have dark oil saturation but is believed caused by organic stain.

\section{Limestone Member}

The limestone or calcarenite is white, light grey to bluish grey, weathers buff to brownish, finely crystalline to very fine and medium grained with sugary texture, sandy to very sandy grading toward limy sandstone. The limestone is bioclastic, composed predominantly of pulverized Inoceramus prisms, thin to medium beds, platy, cross-bedded and strong wave ripples are reported. The unit forms massive cliffs and contains thin olive grey shale-mudstone beds.

This unit ranges from $30^{\prime}$ to $175^{\prime}$ on both sides of the basin. At Limestone Creek (Section No. 42), in the southwest Wrangell Mountains, a large part of the $675^{\prime}$ of calcarenite measured is believed to be limy sandstone.

Throughout the area the limestone unit has oil odor on fresh breaks and reported spotty light brown oil stain, but essentially no reservoir qualities, averaging about $2.5 \%$ porosity and .23 md permeability.

\section{Upper Sandstone Member}

The sandstone is light to dark grey, greenish grey, light brown to brown and black, very fine to very coarse grained, poor to fair sorted, quartzose and arkosic with some volcanic fragments, silty, argillaceous, calcareous and fossiliferous. The unit is thin bedded to massive appearance, cross-bedded in part. A consistent thin olj.ve grey, silty mudstone $\left(10^{\prime}-40+\right)$ is present at the top of the limestone. The upper part of the unit is interbedded with silty, sandy, dark olive-brown mudstone and argillaceous siltstones and sandstones, some are carbonaceous to lignitic. 
This unit ranges in thickness from $0^{\prime}$ to $600^{\prime}$ with up to 495' \pm sandstone with poor to good reservoir qualities averaging about $12.2 \%$ porosity and 63.4 mds. permeability. Strong oil odor and possible light olive brown to brown oil stain is common throughout the Nelchina Area and southwest Wrangells. The black sandstones with greasy appearance are believed organic stained.

Listed below are the Porosity and Permeability values of the sandstone samples submitted to Amoco Research Lab and those gathered from other sources.

NELCHINA FORMATION

Upper Sandstone Member

Sample

Number

$60-\mathrm{R}-27(3)$

$60-R-27(5)$

$60-\mathrm{R}-27(10)$

$\mathrm{L}-134$

$\mathrm{L}-135$

$\mathrm{L}-136$

B -294

B-294A

$B-294 B$

$B-294 C$

B-295

\section{Location}

Limestone Gulch

Section $31,32, T 23 N$, RIOE SM

and Sec. 5, T22N, RIOE, SM

Limestone Gulch

Section 31,32 , T23N, RIOE SM and Sec. 5, T22N, RIOE, SM

Limestone Gulch

Section 31, 32, T23N, RI0E SM

and Sec. 5, T22N, RIOE, SM

Union Section $\mathrm{G}$

NW NW Sec. 4, T22N, RIOE, SM

Union Section $G$

NW NW Sec. 4, T22N, RIOE, SM

Union Section $\mathrm{G}$

NW NW Sec. 4, T22N, R10E, SM

$\mathrm{Nicolie} \mathrm{Ck}$. (Union)

SE SE Sec. 22, T24N, R12E, SM

Nicolie $\mathrm{Ck}$. (Union)

SE SE Sec. 22, T24N, R12E, SM

Nicolie $\mathrm{Ck}$. (Union)

SE SE Sec. 22, T24N, RI2E, SM

Nicolie $\mathrm{Ck}$. (Union)

SE SE Sec. 22, T24N, RI2E, SM

Nicolie $\mathrm{Ck}$. (Union)

SE NW Sec. 23, T24N, RI2E, SM
Porosity Permeability

\begin{tabular}{|c|c|}
\hline$\left(\frac{8}{0}\right)$ & (Md.) \\
\hline 16.1 & 1.1 \\
\hline 24.3 & 669.0 \\
\hline 14.8 & 7.6 \\
\hline 6.7 & 0.0 \\
\hline 5.6 & 0.0 \\
\hline 6.6 & 0.0 \\
\hline 10.0 & 1.5 \\
\hline 11.8 & 2.5 \\
\hline 13.6 & 7.3 \\
\hline 14.2 & 8.4 \\
\hline 12.1 & 0.0 \\
\hline
\end{tabular}

$\overline{135.8} \quad \overline{697.4}$

Porosity Range 5.6-24.3\%, average $12.16 \%$

Permeability Range 0-669 mds., average $63.4 \mathrm{mds}$.

\section{Limestone Member}

CR-92-L

L-133

$\mathrm{L}-197$
Upper Little Nelchina River SE NW Sec. 10, T23N, RIOE SM

Union Section G NW NW Sec. 4, T22N, RI0E, SM

Union Section $\mathrm{H}$ NW SW Sec. 29, T23N, RIOE, SM
$1.3 \quad .05$

$1.1 \quad 0.0$

$0.7 \quad 0.0$ 


\section{$\frac{\text { Limestone Member }}{(\text { Continued) }}$}

L-198

Union Section $\mathrm{H}$

Porosity Range $0.7-5.8 \%$, average $2.45 \%$

Permeability Range: 0-0.9 md., average .23 md.

\section{Lower Sandstone Member}

Billy Ck.-Limestone Gap

CR-172L Sec. 5, T22N, RIOE, SM

Porosity Range: 9.9-13.6\%, average $11.75 \%$

Permeability Range: $1.9-55.8 \mathrm{mds}$, average $28.85 \mathrm{mds}$.

Sample No. with Prefixes B, I, and $W$ are from Borax, and others, 1958.

\section{Nelchina Sand Trends}

Cross sections $E-E^{\prime}, F-F^{\prime}$ (Denver Division Report 154 , Encls. 3 and 4) and G-G' (Encl. 4) and well control provide the control data for the gross sand and trend map of the Nelchina Formation in the Copper River Basin. Several evidences for subaqueous distributary systems are present.

The Chetaslina River and Cheshnina River sections (Nos. 40 and 41 respectively, Powell, 1975, Appendix), originally considered of Upper Jurassic age (Grantz, 1966), are new points of control for the Nelchina Formation (identified palynologically by Pete Groth). Approximately 1,000'+ calcareous sandstone is present at the Cheshnina River section (Encl. 4). Core analysis of a sample at bottom of the section shows $9.9 \%$ porosity and permeability of $55.8 \mathrm{mds}$. The sandstones are grey to brownish-grey, fine to coarse grained with scattered pebble conglomeratic lenses. A few plant (fern) fossils, carbonized wood and part of an ammonite was found. Only $520^{\prime}$ of sandstone was measured on the Chetaslina River. About $120^{\prime}$ of silty limestone to limy siltstone with ? Inoceramus prisms and possible abundant crushed pelecypods shells overlie the sandstones. Both sections are dipping about 20-25 $\mathrm{SW}$, basinward.

The Nelchina Formation is just as prospective in the western part of the basin as the eastern part where Amoco has an exploration contract with the Ahtna Native Corporation.

\section{Ahtna Corporation Contract Area}

The geologic column for this area (outlined by black tape) is shown by the Pan American \#1 Moose Creek Unit (Fig. 3) located in the southwest part of the area. Only 7,020' of Lower Cretaceous to Tertiary beds are present above the Lower Jurassic (?) -Talkeetna Formation. The Middle Jurassic - 
Tuxedni sandstones and Upper Jurassic-Chinitna Formation and Naknek sandstones have been removed by pre-Lower Cretaceous erosion (see Encl. 3). The Nelchina Formation in the Moose Creek well is 1,083' thick, containing upper and lower sand zones totally about 480-550' in thickness. The well blew out at 6,074' while drilling and flowed some gas and salt water $(18,322 \mathrm{PPM})$ at the rate of $848 \mathrm{BWPH}$.

\section{Western Basin Area}

The Mobil No. I Salmon Berry Lake Unit blew out and flowed salt water $(21,600$ PPM) and some gas from a 50 ' Nelchina sand at 2,400' which is interpreted to be part of an offshore bar (Bishop, 1965). The interpreted sand distribution is shown on Enclosure 1. The seismic area of interest is shown by dashed orange tape.

\section{Upper Susitna Valley and Eastern Alaska Range}

The occurrence of Neocomian rocks in these areas have been briefly mentioned in the geological history section. Up to 10,000' of marine and subaerial andesitic volcanic, volcanic-clastic rocks and with minor marine and continental sedimentary rock near the base was described as the Chisana Formation in the Eastern Alaska Range-Nuzotin Mountains (Richter and Jones, 1973, Richter, 1976, and Miers and Taylor, 1975). The volcanics and volcanic clastics are believed to represent a volcanic arc assemblage and the basal dark grey argillites, thin bedded greywackes, pebble to cobble conglomerates and tuffaceous mudstones represent continental to shallow and deep water deposits. These rocks conformably overlie the deep marine turbiditic sequence of graded argillites and greywackes and mudstones of the "Nuzotin Mountain" sequence of Upper Jurassic and Lower Cretaceous age (Richter and Jones, 1973).

In the Upper Susitna Valley area, several thousand feet of dark fine grained argillites and rhythmic interlayer argillite and greywacke, and overlying argillites, greywackes and conglomerates are reported from the Upper Chulitna district (Clark and others, 1972). Probably represent deep basin deposits, as in the eastern Alaska Range.

\section{Environments of Deposition}

The Nelchina Formation is a shelf deposit, more specifically shore, nearshore, deltaic, nearshore, bars and shoal deposits which onlap the eroded surface of the Upper Jurassic-Naknek Formation in the western area and the Triassic shales, limestones and lava beds, and igneous intrusives in the Wrangell Mountains and Permo-Pennsylvanian rocks on the Northern

Chugach Mountains. The diagrammatic cross-section on Enclosure 1 indicates several advances of the Neocomian seas. Volcanic arc and shallow to deep water deposits are reported from the eastern Alaska Range and Upper Susitna Valley areas.

\section{Source Rock Information}

The source rock evaluation map (Encl. 9) shows the distribution and results of samples collected from the area. The oil odor and staining has previously been described in the conclusions and the text. Two subsurface samples showed fair gas and wet gas generating capability and early and early peak generation. The natural crude extract from the Nelchina section in the Moose Creek well as well as the odor and staining on the outcrop point to a migrated oil in the basin. 
Matanuska (basal) and Kennicott Formations (Albian Age) Western Copper River Basin

In the Nelchina Area, Albian age (basal Matanuska Formation) rocks disconformably overlie the Nelchina Formation and with angular unconformably overlie the Lower Jurassic-Talkeetna Formation on the northern front of the Chugach Mountains. In the Limestone Hills area, approximately $515^{\prime}$ of Albian rocks are present in the Upper Bubb Creek Section (No. 12 in Appendix, Powell, 1975) and in the Upper Flume Creek area. The basal section is nonmarine sandstone and coalbearing claystones (Photos 65-66) overlain by littoral and nearshore sandstones and siltstones of early early Albian age and an upper unit of siltstone and silty claystone of late early Albian age which are overlain disconformably by siltstone and claystone of Upper Cretaceous-Late Campanian or Mestrichtian Age (Jones and Grantz, 1967). Along the northern front of the Chugach Mountains, the basal unit is composed of near shore marine beds of coarse to conglomeratic sandstone (up to $400^{\prime}$ ) which rests with angular unconformity on the Talkeetna Formation. The overlying siltstone and silty claystone are thicker in the southern part of the area and are disconformably overlain by beds of Upper CretaceousCenomanian to Turonian Age (Ibid).

\section{Environments of Deposition}

The absence of the Tuxedni through Nelchina Formations, coarsing of sediments northward, nearshore deposits, and various ages of disconformable overlying rocks indicate that the Chugach Mountains were positive and a source area during Albian and much of Upper Cretaceous-Matanuska time (Grantz and Jones, 1960, Grantz, 1964). The continental and nearshore deposits to the north and the disconformable relationship of the overlying beds suggest that a larger source area is located to the north (Ibid). A composited section of the Albian age rocks are shown on enclosures 3 and 6 and are correlated to the same age rocks on the east side of the basin.

\section{Reservoir Qualities}

The sandstones of the basal Matanuska are considered poor reservoir objectives in the western area because of lack of permeability in the outcrop samples. The porosity ranges from 5.1\% to $15.6 \%$ and averages $9.56 \%$. The permeability ranges from 0 to $8.5 \mathrm{mds}$. and averages $1.54 \mathrm{mds}$.

\section{Eastern Copper River Basin}

A similar depositional relationship is seen in the eastern (mostly southeastern) part of the region. The composite Albian age rocks in the southwest Wrangell Mountains and the Upper Chitina Valley are 1,450' to 2,150' thick, respectively (Encls. 3 and 6 ) and include the Kennicott Formation (as defined by Jones and Mackevett, 1969), parts of the Schulze, Moonshine Creek, and Chititu Formations.

The Kennicott Formation ranges from a few feet to 2,150'+ in thickness and unconformably, with no apparent discordance, overlies rocks from the Lower Cretaceous-Nelchina Formation in the southwest Wrangell Mountains; rests with sharp angular unconformity on the Lower Jurassic and Upper Triassic-McCarthy Formation (photo 116) Upper Triassic-Nizina and Chitistone Limestones, Middle and Upper Triassic-Nikolai Greenstone (lava beds, photos 110-111) in the McCarthy area of the 
southern Wrangell Mountains; and the Permo-Pennsylvanian Skolai Group in the Upper Chitina Valley area.

\section{Upper Chitina Valley-McCarthy Area}

The Kennicott Formation consists of a basal conglomerate and fine grained to pebbly sandstone from $0^{\prime}$ to $100^{\prime}$ thick, locally black shale with clasts of limestone from the McCarthy Formation; and overlying sandstone, siltstone and shale with calcareous concretions. At the type locality (Ibid) sections 14, 15 and $22, T 4 S, R 12 E$ CRM a $75^{\prime}$ conglomerate composed of pebbles to boulders is at the top of the sequence (see Bear Creek Section No. 55, Powell, 1975, Appendix). The basal conglomerate was not present at this section. The sandstones are grey to greenish-grey, fine grained, calcareous, fossiliferous, and tight to poor porosity. Far to the northeast at Regal Glacier section (photos 109111) in Sections 28 and 33, T2S, RI6E, CRM the basal conglomerate is overlain by dark grey to black carbonaceous and lignitic claystones and shales to lignite, interbedded with carbonaceous cross-bedded, tight sandstone that are of continental origin.

\section{Southwest Wrangell Mountains}

The composited thickness of the formation in the southwest Wrangelis is about 2,150' and is composed of a poorly exposed $250^{\prime}$ basal sandstone unit and the overlying $1,250^{\circ}$ dark shale unit, silty and with minor silúcous siltstones and the top and numerous limestone concretions and calcareous siltstone zones near the base in Kuskulana Pass area (Grantz, and other, 1966, and Chokosna River Section No. 50, Powell, 1975, Appendix and photo 89). The upper part near Mount Drum is 650' of shallow marine, siltstone and shale with a thin porous sandstone near the base (photos 79-82). Also contains a bed of granite wash which was derived from an eroded granodiorite intrusive (photo 82 ) on which the unit onlaps (Ibid, and Snider Peak section No. 39, Ibid).

\section{Reservoir Qualities}

Thin sandstones (10' thick) in the lower part of the Upper Kennicott Formation at Snider Peak section have poor to good reservoir potential if they thicken in the subsurface to the west. The porosity ranges from $10.2 \%$ to $19.4 \%$ and average $14.8 \%$. The permeability ranges from $5.1 \mathrm{mds}$. to $38.5 \mathrm{mds}$. and average $21.8 \mathrm{mds}$. The sandstones and conglomerates in the McCarthy area have poor to tight visual porosity.

Listed below are the porosity and permeability of the samples submitted to Amoco Research Lab and those gathered from other sources.

Basal Matanuska and Kennicott Formations (Albian Age)

Sample

Number

CR-195L Kennicott Sandstone

60-R-39 Kennicott Sandstone

60-R-31 Basal Matanuska

CR-77-L Basal Matanuska
Porosity Permeability

(\%) Mds.

Snider Peak NE Sec. 12, T3N, R4E, CRM

$19.4 \quad 38.5$

Snider Peak

NE Sec. 12, T3N, R4E, CRM

10.25 .1

5.10 .1

Sandstone SE Sec. 28, T24N, R9E, SM

$15.6 \quad 1.13$ 
Sample

Number

Member $\quad$ Lithology

Porosity Permeability

L-138

Basal

Sands tone

Location

$(\%)$

Mds.

Matanuska

$L-147$

Basal

Sandstone

NW Sec. 12, T20N, RI2E, SM

12.8

$L-148$

Basal

Sandstone

SW Sec. 11, T20N, R12E, SM

5.5

0.0

$L-181$

\section{Basal}

Sandstone NW Sec. 5, TIN, R9W, CRM

$10.6 \quad 0.0$

Matanuska

W-155

Basal

Sandstone NE Sec. 12, T20N, RI2E, SM

8.31 .1

$\overline{96.6} \overline{54.4}$

Porosity Range: 5.1-19.4\%, average 10.73\%

Permeability Range: 0-38.5 mds., average $6.4 \mathrm{mds}$.

Environments of Deposition

The Kennicott Formation is of the same age as the basal Matanuska Formation, i.e., early early Albian and late early Albian. The formation is of shallow marine origin and represents a northward transgressing unit which becomes younger in the northern part of the McCarthy area where a continental infuence is seen. In the southwest Wrangell Mountains the Kennicott Formation overlaps the Nelchina Formation completely. At Snider Peak the late early portion of the sequence onlaps a granodiorite intrusive of probable Late Jurassic age and is in close proximity to beds of the Skolai Group-PermoPennsylvanian age. Basal Matanuska and Kennicott sediments appear to have been deposited in a narrow seaway particular in the southwestern part of the basin. No outcrop data in southern part of Upper Chitina Valley, but possible that eastern Chugach Mountains were positive in part.

\section{Copper River Basin Subsurface}

No microfossils of definite age have been found in the Copper River Basin subsurface. Based on the presence of species reported in Albian and Cenomanian of other areas, and the outcrops on both sides of the basin; Albian age shales are shown on Enclosures 3 and 6 . Conflicting data from several sources are shown on Enclosure 6. It is suggested that all available well samples be re-evaluated along with subsurface samples collected in July, 1976. The Kennicott Formation is a possible secondary objective in the eastern portion of the basin.

\section{Restricted Albian Age Rocks - McCarthy Area}

\section{Schulze Formation (Albian and Cenomanian Age)}

The Schulze Formation (data from Jones and McKevett, 1969) has limited distribution and disconformably or with probable slight angular unconformity, overlies the Kennicott Formation in local areas. The formation is composed of thinly interbedded siliceous shales, siltstone and sandstone with a maximum thickness of about 200'. The rocks weather to a conspicuous yellow-brown color (see Photo No. 117, and Northeast Nikolai Mine Section No. 57, Report 154, Appendix). The unit is conformably overlain by the Chititu Formation and locally unconformably overlain by Tertiary-Frederika 
Formation and is cut by dikes and sills of Tertiary age. Jones and Mackevett (1969) reports the formation was "probably deposited in an isolated marine basin from which the abundant clastic debris of the Moonshine Creek Formation was restricted."

Moonshine Creek Formation (Albian and Cenomanian Age)

This formation (Ibid) ranges from a few feet thick to 3,500' in the type locality in the McCarthy C-4 Quandrangle, where it unconformably overlies the Triassic-N. Kolai Greenstone. It disconformably overlies the Kennicott Formation at other places, conformably overlain by the chititu Formation at a few places and unconformably overlain by the TertiaryFrederika Formation (see Contact Gulch Section No. 60 , Report 154, Appendix) and cut by a few sills and dikes of Tertiary age.

The formation is composed of shales, siltstone, sandstones and some conglomerates, it is apparently a facies of the Chititu Formation and to a lesser extent the upper part of the Kennicott and Schulze Formation. Jones and Mackevett (1969) believed the rocks were deposited in a rapidly sinking basin.

\section{Chititu Formation (Albian through Campanian Age)}

The basal part of this thick sequence of dark shales is of Albian Age. The formation conformably overlies the Kennicott Formation and locally the Schulze and Moonshine Creek Formations. It is intruded by Tertiary granodiorite plutons, dikes and sills (see MacColl Ridge-Copper Creek Section Nos. 61 and 72, and Niziana River Section No. 56, Powell, 1975, Appendix).

\section{Source Rock Information}

The source rock information map (Encl. 9) shows the distribution and results of samples collected from the area. Six of the eight samples evaluated show fair to very good gas and wet gas generating capabilities on the eastern side of the basin. The stages of maturity range from pregeneration (one) to early peak, peak and early advanced. One fair oil source rock at past peak level of diagenesis is present in the southwest Wrangell Mountains and one nonsource rock sample was tested on the west side of the basin (Harwood, 1975).

\section{UPPER CRETACEOUS}

\section{Matanuska Formation and Coeval Deposits}

The Matanuska Formation crops out in the southeastern Talkeetna Mountains, upper Matanuska valley, along the northern front of the western Chugach Mountains, in the southwestern part of the basin, and is present in the subsurface across the Copper River Basin. The total formation is best exposed around the northern flank and eastern end of Sheep Mountain and on Syncline Mountain, where 9,550' of Upper Cretaceous rocks of Cenomanian to Maestrichtian age was measured (photos 55-64, Encl. 6, and Syncline-Sheep Mountain Section No. 1 in Appendix, Powell, 1975).

The Lower Cretaceous-Albian portion which varies from $515^{\prime}$ on upper Bubb Creek and Upper Flume Creek to approximately 
$1,200^{\prime}$ on the north front of the Chugach Mountains is not present on Sheep Mountain; and as the top of the section is eroded the total formation easily exceeds 10,000'.

The formation consists of a monotonous sequence of predominantly medium grey shales calcareous and silty in part with occasional thin beds of siltstone to sandstone and conglomerate, scattered limy concretions. Two distinct sandstone zones are developed, a basal unit and an upper zone about 900' from the top of the section. The basal Matanuska Sand zone (Cenomanian age) overlies with angular unconformity the Talkeetna Formation on Sheep Mountain (photos $58,59,63)$ and similarly on the north front of the chugach Mountains, but here the basal beds are of Lower CretaceousAlbian age. The Upper Cretaceous-Matanuska Formation disconformably overlies the Albian portion in the Upper Flume Creek and Upper Bubb Creek areas. Basal units of younger age onlap Lower Cretaceous and older rocks to the north and west (Grantz, 1965).

\section{Basal Sandstone Unit}

The sandstones of the basal unit (photos 58-59) are grey, very fine to fine grained, hard, calcareous, glauconitic and cross bedded in part, thin to thick bedded, weathering to flaggy or angular blocks. The sandstones are fossiliferous, containing ammonites and pelecypods (photo 61), trace fossilsworm trails or burrow? (photo 60) and few fragments of fossil wood. The basal zone is about 350' thick and includes over 100' of sandstones interbedded with siltstone and shale.

\section{Depositional Environment and Reservoir Qualities}

The basal sandstones were deposited in a shallow-nearshore, low energy marine environment. Source of the sediments may have been either from the north or from the south. The sandstones have poor reservoir qualities, averaging about $9 \%$ porosity, but only .24 md permeability. In the subsurface correlated units in the basal part of the Matanuska Formation have poor to fair sand development but very poor porosity and permeability (Encl. 6), but may be more prospective northward toward a source area.

\section{Upper Sandstone Unit}

In the upper part of the shale sequence, 900' from top of the section, 450-500' of sandstone is developed within a 1,000't interval (Photo 57). The sandstones are medium grey to brown, very fine to fine grained, silty, argillaceous, well indurated, in thin to thick beds alternating with thin interbeds of siltstone and shale. The sandstones dominate in the upper part and shale becoming dominant down section. Soft sediment deformation (small scale) contortions occur in the lower part of the sand zone and large scale contortions occur below this unit in an adjacent drainage.

Depositional Environment and Reservoir Qualities

The relatively uniform thin and thick sandstones alternating with thin beds of siltstone and shale and soft sediment 
deformation suggest deeper water deposition similar to the thick uniform shales, than the basal sands. The sands are believed derived from a large source area to the north. The sandstones are rated as poor reservoir objectives, primarily because of permeability. Porosities range from 4.9-21.9\%, averaging about $12 \%$, and permeabilities vary from .05-6.6 md, averaging $2.13 \mathrm{mds}$. The best sample of $21.9 \%$ porosity and 6.6 mds was collected by a Union-Ohio field party (Borax, and others, 1958) and came from the southwestern portion of the basin. Its actual position in the syncline - Sheep Mountains section is unknown but thought to fall within the upper part of the sequence.

Listed below are the porosity and permeability values of the sandstone samples submitted to Amoco Research Lab and those gathered from other sources.

\section{MATANUSKA FORMATION}

\section{Upper Sandstone Member}

\begin{tabular}{|c|c|c|c|}
\hline $\begin{array}{l}\text { Sample } \\
\text { Number } \\
\end{array}$ & Location & $\begin{array}{l}\text { Porosity } \\
\text { 응 }\end{array}$ & $\begin{array}{l}\text { Permeability } \\
\text { Mds. }\end{array}$ \\
\hline CR-1025L & $\begin{array}{l}\text { Mouse Creek } \\
\text { Sec. } 28 \text { T22N, RI0E, SM }\end{array}$ & 4.9 & 0.05 \\
\hline CR-2010L & $\begin{array}{l}\text { Syncline Mountain } \\
\text { SE Sec. 12, T2IN, RIOE, SM }\end{array}$ & 6.8 & 1.55 \\
\hline CR-2010L & $\begin{array}{l}\text { Syncline Mountain } \\
\text { SE Sec. 12, T2lN, RI0E, SM }\end{array}$ & 10.9 & 3.12 \\
\hline CR-2020L & $\begin{array}{l}\text { Syncline Mountain } \\
\text { NE Sec. 13, T2lN, RIOE, SM }\end{array}$ & 11.4 & 0.39 \\
\hline$C R-R-3$ & $\begin{array}{l}\text { Syncline Mountain } \\
\text { NE Sec. 13, T2IN, RIOE, SM }\end{array}$ & 15.2 & 0.11 \\
\hline$B-251$ & $\begin{array}{l}\text { Strat Section } F \\
\text { SW Sec. 7, T2IN, RIIE, SM }\end{array}$ & 12.2 & 2.10 \\
\hline$B-252$ & $\begin{array}{l}\text { Strat section } F \\
\text { SW Sec. 7, T2IN, RIIE, SM }\end{array}$ & 10.6 & 3.10 \\
\hline$L-119$ & $\begin{array}{l}\text { Strat section } F \\
\text { SE Sec. 33, T3N } \\
\text { R8W, CRM }\end{array}$ & $\frac{21.9}{93.9}$ & $\frac{6.60}{17.02}$ \\
\hline
\end{tabular}

Porosity Range 4.9-21.9\% average 11.73

Permeability Range .05-6.6 mas average 2.13 mds.

\section{Basal Sandstone Member}

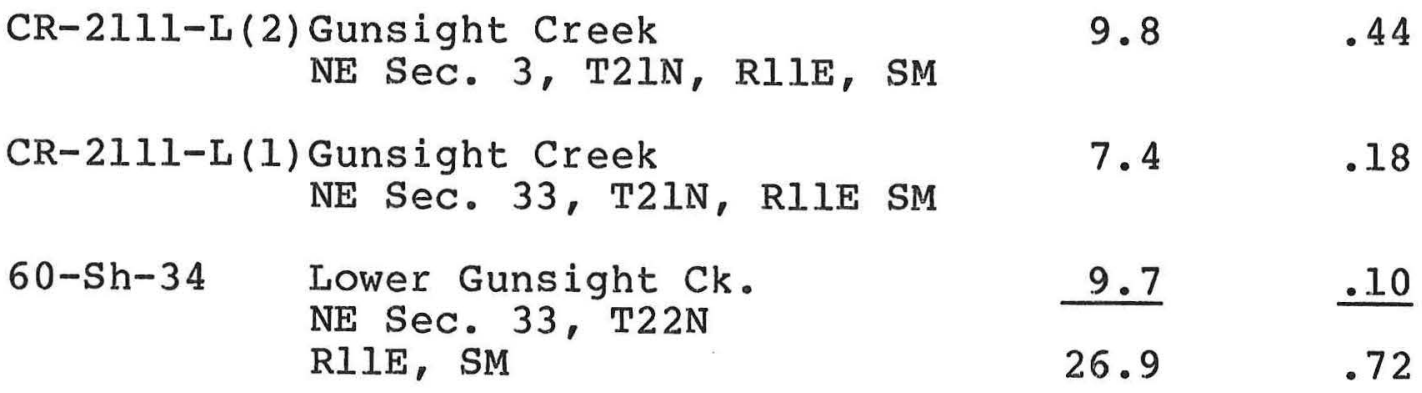

Porosity Range $7.4-9.8 \%$ average $8.96 \%$

Permeability Range .10-44 mas average .24 ma. 


\section{Coeval Formations}

Upper Cretaceous sediments are not present or not identified in the southwest Wrangell Mountains. The Lower and Upper Cretaceous-Schulze and Moonshine Creek Formations have been described under the Lower Cretaceous-Albian age section. described under the Lower Cretaceous-Albian age section. The Chititu and MacColl Ridge Formations are the principal Upper Cretaceous sediments that are well exposed in the McCarthy area (Encl. 1 of Powell, 1975). see section H$\mathrm{H}^{\prime}$ (Encl. 3) for regional correlations and section J-J' (Encl. 6) for possible subsurface correlations across the Copper River Basin.

\section{Chititu Formation (Albian into Campanian Ages)}

The Chititu Formation consists of shale, black, rare thin reddish zones, soft, splintry to blocky, weathers greyishbrown to brown, and occasionally are calcareous and silty. A minor interbedded $50^{\prime}$ zone of thin shales, siltstones and sandstones with a few pebbles and cobbles is present, about $800^{\prime}$ from the top of the sequence, in many scour and fill lenses. This unit contains scattered to locally abundant limy concretions which are fossiliferous in part and show traces of worm burrows or trails; and could possibly be a distal end or lentil from a tongue of the overlying MacColl Ridge Formation. Igneous intrusions of Tertiary age are common (photos 106-108) but in the smaller dikes and sills checked have only altered the surrounding shales a few inches or a few feet. Larger plutons are present in the area.

A maximum thickness of $5,000^{\prime}$ is estimated for the Chititu Formation as composited from the MacColl Ridge-Copper Creek sections (photos 112-115; Encl. 3, Sections 61 and 62 in appendix, Powell, 1975). Mackevett (1970c) has estimated up to $9,000^{\prime}$ of section but accuracy is questioned due to folding and lack of markers. The formation overlies the Kennicott, Schulze or Moonshine Creek Formation with apparent conformity or minor disconformity. At a few places the sequence overlies pre-Cretaceous rocks with apparent unconformity (Mackevett, 1970c). The MacColl Ridge Formation conformably or with very slight disconformity overlies the Chititu Formation. For additional details refer to Jones and Mackevett (1969), MacKevett (1970, 1970c).

\section{Depositional Environment and Age}

The Chititu Formation is considexed of moderately shallow to deep marine origin. The formation is apparently in facies with the coarser clastics of the Moonshine Creek and Schulze Formations, and contains inoceramus and ammonite fossils which dates the main part of the section as Late Cretaceous-Cenomanian to Campanian. The basal part may be of Albian age (Ibid). 
The MacColl Ridge Formation (photos 112-114, Encl. 3, Sections 61 and 62, Powell, 1975) is a thick massive sequence of sandstone, grey to greenish grey, weathers brown, very fine to very coarse grained and grades into pebble-cobble ( $r$ are boulder) conglomerates, which are supported by fine clastic matrices. The sequences contain many scour and fill structures giving a lensing appearance with the channel fill showing graded beds. Interbedded units of sandstone, siltstone and shale are minor. Some poorly preserved plant remains and fragments of Inoceramus and ammonites have been reported. Small igneous intrusions and dikes and silts have cut the formation.

The formation is estimated at 2,000-2,500' in thickness, caps the ridges and high peaks and conformably or with slight disconformity overlies the Chititu Formation. The top is eroded or covered by Quaternary material (Jones and Mackevett, 1969; Mackevett, 1970, 1970c).

\section{Depositional Environment, Age and Reservoir Qualities}

The formation probably represents the final Cretaceous regressive event and is believed deposited under very nearshore and possibly continental conditions. No diagnostic fossils have been found so based on stratigraphic position and Tertiary intrusives the formation is considered Campanian or Maestrichtian. The sandstones examined in the lower portion of the sequence had poor to tight visual porosity. It is possible that equivalent sediment may be present in the northern part of the eastern Copper River Basin and could have been subjected to a better wave, current or tidal energy.

\section{Eastern Alaska Range}

A sequence of nonmarine rocks $0-1,200^{\prime}$ thick is reported by Richter and Jones (1973) as unconformably overlying the Lower Cretaceous rocks in small local areas in the eastern Alaska Range. The unit is composed of conglomerates and sandstones with minor coaly beds. Based on well preserved plant remains a Late Cretaceous age was suggested (Ibid).

These rocks underlie the Tertiary-Wrangell Lava as the Frederika Formation does to the south and may be of equivalent Tertiary-Miocene age.

\section{Source Rock Information}

The source rock evaluation map (Encl. 8) shows the distribution and results of 20 samples collected from the region. On the west side of the basin, the Matanuska shales, based on two samples, is rated as poor to fair oil source beds in past peak to early advance state of diagenesis, and from six samples, as a poor to fair gas source bed in a similar stage of maturity (Harwood, 1975). Within the basin, at the Moose Creek Unit test, two samples show the Matanuska shales as nonsource and three samples show a poor gas generating capability at pregeneration to early generation stage. A small amount of benzene (oil indicator?) was recovered from the Matanuska Formation at this well (Byington, 1973). A more positive oil indicator - two quarts of dead oil and asphalt were bailed from the Aledo test in T2IN RI2E, SM. 
In the Upper Chitina Valley-McCarthy area one sample rates the lower Chititu as a poor oil generating source at past peak stage of diagenesis, and a poor gas source in four samples, nonsource in one sample, at peak to late peak stage of diagenesis. The Moonshine Creek Formation is rated as a nonsource to good wet gas generating capability from two samples, at early peak to peak diagenesis.

\section{TERTIARY}

Outcrop of nonmarine Tertiary sediments of various reported ages are exposed in the eastern Talkeetna Mountains, southwest portion of the basin and in the subsurface as well, south flank of the Alaska Range, and in the Wrangell Mountains (Encl. 3, 6; Encl. 1 of Powell, 1975).

\section{Western Copper River Basin}

Continental sequence of fluviatile sandstones, pebble conglomerate, siltstones and claystone with coaly beds and thin coals are exposed on the western flank of the basin and spotty outcrop along the southern portion of the western half of the basin (Grantz, 1965). The maximum known thickness of this sequence is about $2,400^{\prime}$ arilled in the Atlantic No. 1 Rainbow Federal, Sec. 31, T8N, R5W, CRM. The sandstones have fair to good porosity and permeability as evidenced by a grab sample on Tyone creek (Sec. 20, T6N, RI0W, CRM) which analyzed $12.0 \%$ porosity and 1,874 mas of permeability. This formation unconformably overlies older rocks ranging in age from Upper Cretaceous to Lower Jurassic. These Tertiary rocks are considered of Miocene and younger Tertiary age and at least in part equivalent to the Frederika Formation of the Wrangell Mountains (see proposed correlations on Encl. 3 ). Over $3,000^{\prime}$ is considered a reasonable thickness to expect in the deeper western portion of the basin.

In the Caribou-Billy Creeks area, T22N, R10E, SM, a thinner but similar sequence of Tertiary sediment overlain by Tertiary volcanics have been mapped as the Chickaloon Formation of Paleocene age (Grantz, 1965). Palynology samples show a younger Tertiary-Miocene or younger age (per D. E. Engelhardt). The volcanic flows are considered in part equivalent to the Wrangell Lava. In the Chitna Creek area Tertiary volcanic and sediments unconformably overlie Cretaceous and older rocks (photos 31, 36).

\section{Wrangell Mountains}

About 2,000' of continental conglomerates, sandstone, siltstone, shale, carbonaceous shale and lignite, intercalated with Wrangell Lava have been named the Frederika Formation and dated as Miocene age (Photos 89, 100, 109).

\section{Southern Alaska Range}

An unnamed Tertiary sequence over 575' was sampled at the Phelan Creek Section (No. 36, Powell, 1975) and consisted of conglomerates, sandstone, siltstones, shales, carbonaceous and lignitic shales and claystone (Photos 69-70). No basal contact was observed. The unit is considered of Miocene or younger Tertiary age. 
Approximately $600^{\prime}$ of the hard, massive Gakona Conglomerate (Mendenhall, 1905), silty sandstones and siltstones were measured at the West Fork of the Chistochina River Section (No. 37, Powell, 1975) and is considered the same age as the Phelan Creek sequence. Additional claystones and shales are present above the conglomerate. An estimated sequence of $2,000^{\prime}$ is reported in the area and east of the Gakona Glacier. The conglomerate caps an igneous based ridge (Ibid).

\section{Source Rock Information}

Two source rock samples (Encl. 7) show that the Tertiary section has nonsource to good generating capability, but are in a pregeneration stage of diagenesis (Harwood, 1975).

\section{TERTIARY-QUATERNARY}

\section{Wrangell Lava}

A thick sequence of subaerial lava flows with lesser pyroclastics and continental sediments are well displayed in the huge Wrangell Mountains lava pile (photos 74, 79, $80,100,117)$. Numerous igneous intrusion, dikes and sills cut the lavas. Volcanism commenced in the Miocene time and continued through the Quaternary, literally to the present as smoke, vapors and ash falls have been reported and photographed (Mendenhall, 1905).

\section{Talkeetna Mountains}

An unnamed volcanic sequence unconformably overlying Tertiary continental sediments and older formations (Photos 31 , 36) has been mapped in the western portion of the Nelchina area (Grantz, 1965). The section is at least several thousand feet thick (Photo 6 ) and was deposited in late TertiaryMiocene to Quaternary time (at least in part coeval to the Wrangell Lava).

\section{QUATERNARY}

Glacial and alluvial deposits cover most of the Copper River Basin and Chitina Valley. A thickness of approximately $700^{\prime}$ has been measured along the Copper River Valley and could easily exceed 1,000' in maximum thickness.

\section{STRUCTURE}

\section{Regional Discussion}

The Copper River Basin is a large structural and topographic basin covered by Quaternary glacio-alluvial deposits and surrounded by mountain ranges composed of folded and mostly metamorphosed Paleozoic volcanics, volcaniclastics, marine 
sedimentary rocks and igneous intrusives; early Mesozoic sedimentary and igneous rocks, which are metamorphosed in part; and Cenozoic continental sedimentary rocks, volcanics, igneous and glacial deposits. The basin (Matanuska geosyncline) was injtially formed by a major orogeny near the end of Early Jurassic time as a depression in the folded and metamorphosed contents of an older eugeosyncline (volcanic arc). The present structural framework resulted from an orogeny in Late Cretaceous-Early Tertiary time (approximate Laramide time), modified by erosion, Late Tertiary-Quaternary uplift and the periods of glaciation.

\section{Plate Tectonics}

The tectonics and formation of the entire southern Alaska have resulted from the interactions of approaching, colliding, joining and consumption of oceanic and continental plates, as discussed by numerous authors. Following is a generalized and slightly modified summary of a plate tectonic model proposed by Richter and Jones (1973):

1. A Late Pennsylvanian volcanic arc system was formed directly on oceanic crust (Kula or older oceanic plate) caused by the southward subduction of the North Americancontinental plate which had a leading edge of oceanic crust.

2. The oceanic leading edge was mostly consumed by Early Permian time and the volcanic arc and continent began to impinge. Volcanism waned and parts of the arc subsided followed by marine sedimentation.

3. The arc collapsed against the continental plate, underthrusting stopped during Early Triassic time, accompanied by uplifts, intrusions, local metamorphism and emplacement of alpine ultramafic rocks along the suture zone. Csejtey (1975) in the northwest part of the region concluded that the arc system was added to the continent during Cretaceous time.

4. The Kula plate, after breaking its join with the volcanic arc, began subducting under the arc still coupled to the continent.

5. In Middle to Late Triassic time, much of the continent emerged and thick subaerial flood basalts were deposited over remnants of the volcanic arc followed by progressive subsidence of continental platform during which thick carbonate muds, thinner limestones units to deeper water shales, impure cherts and limestones were deposited in the east, whereas the waning stages of volcanism may have continued to the west.

6. Active subduction in which the oceanic plate was consumed continued through the Jurassic and Cretaceous time. Thick clastic sediments deposited along continental margin and related linear trenches formed far behind the continental margin. Unstable shelf deposition in forearc basins accompanied by plutonism, deformation and erosion which climax in early Tertiary time (approximate Laramide period).

7. The Miocene time was marked by shallow plutonic activity, continental sedimentation, large continental volcanism (Wrangell lava pile forming in midperiod) and glaciation covered much of the area. The oceanic ridge separating the Kula plate from the Pacific plate disappeared into 
the trench followed by impingment of the Pacific plate on the continent by late Miocene time. The colliding of the Pacific and continental plates at a different angle and slower speed resulted in a right-lateral transform fault (Denali fault) at the Pennsylvanian arc-continental suture.

8. During Late Tertiary into Quaternary, the compressional stresses caused by the motion of the Pacific plate, which did not underthrust, were relieved by uplift and lateral movement along the Denali fault and related systems. The decouple southern part of the North American plate, west of the Denali-Totschunda fault systems, is moving with the Pacific plate (for additional details see Berg and others, 1972, Richter and Jones, 1973, Clark and others, 1972, and Csejtey, 1975).

\section{LOCAL STRUCTURE}

\section{West Copper River Basin}

Structures of the Nelchina area, such as the sheep and Horn Mountains are large anticlinal features that plunge northeastward. Structural cross-section A-A' (Encl. 2 of Powel1, 1975) shows the NW-SE interpretation from the Talkeetna Mountains across the Nelchina area on to the Chugach Mountains (Grantz, 1965).

The Castle Mountain and Caribou Faults are two rightlateral strike-slip fault systems which trend easterly across the Nelchina area and divide it into three blocks and which Grantz (1965) interprets as having moved dissimilar stratigraphic sequences adjacent to each other. These two faults merge in the Central Matanuska Valley and form the north bounding fault of the lower Matanuska Valley.

\section{East Copper River Basin}

Structures of the southwest Wrangells trend northwestward parallel to the strike of the beds with much high angle reverse faulting, see structural sections $B-B^{\prime}$ and $C-C^{\prime}$ (Ibid). Southwest basinward dips of $20^{\circ}-25^{\circ}$ SW were noted at the Lower Cretaceous-Snider Peak, Chetaslina and Cheshnina River Sections.

The structural grain of the McCarthy area-Upper Chitina Valley is also northwestward. The structural interpretation of the eastern Wrangells is shown by Section D-D' (Ibid).

\section{North Copper River Basin}

Structural data along the southern Alaska Range and the foothills show from east to west: northwest trends, east to west trends and finally southwest trends. The PermoPennsylvanian metavolcanics outcrops around the northern flank of the basin show an east west alignment, no actually structural features are known. 


\section{South Copper River Basin}

Outcrop patterns and trace of the Border Range fault roughly show a typical arcuate pattern similar to the north side of the basin.

\section{Central Copper River Basin}

From the structural grain described around the basin a dominantly east-west trend was anticipated for the central portion of the basin. Original seismic data in the eastern part (Ahtna contract area) tended to support this alignment. With additional seismic control and reinterpretations multiple trends are apparent, possibly because much of the area is at intersection or turnpoint for the trends?

\section{Tectonic styles}

Vertical movement of "basement" blocks and compressional forces are the structural styles dominating the region south of the Denali fault. Mapped major thrust faults in the McCarthy region (photo 118; Moffit, 1938; Mackevett, 1965a, $1970,1970 \mathrm{~b})$. The southwest Wrangell Mountains (Sections B$B^{\prime}$ and C-C' of Encl. 2, Powell, 1975) Chugach Mountains (Border Range fault) show compressional influences as well as the strongly folded and faulted trench deposits of the eastern Alaska Range and probably the same within the Maclaren metamorphic belt. Lateral and vertical movement is prominently shown by the right lateral north bounding Denali fault and in the southwest part of the basin the hoist blocks of sheep and Horn Mountains bounded by the dextral Castle Mountain and Caribou Creek fault systems and the Talkeetna Mountain front north of the main Castle Mountain fault show strong vertical uplift as well as strike-slip displacement. It is unknown how far these fault systems extend into the Copper River Basin.

Subsurface data is too sparse to totally type the basin structurally.

\section{SOURCE ROCK EVALUATION}

Sixty-two Tertiary to Paleozoic outcrops and subsurface rock samples from the Copper River Basin Area have been analyzed for source rock potential. Twenty-one of these samples represent formations of Upper and Lower Cretaceous and Upper and Middle Jurasic ages, were from the eastern flank of the Talkeetna Mountains (commonly referred to as the Nelchina Area) which borders the western margin of the basin. Three samples of Tertiary and Permian age shales were from the south flank of the Alaska Range (along far northern basin flank). Twenty-six samples of Upper, Middle and Lower Jurassic and Upper and Lower Cretaceous were from the eastern flank of the basin (southwest Wrangell Mountains) and the upper Chitina Valley-McCarthy area. The final twelve samples were cuttings from two wells located around the midportion of the basin and represent Middle and Lower Jurassic and Upper and Lower Cretaceous ages. 
These data along with other evidences of hydrocarbons are depicted on a series of source rock evaluation maps (Encls. 7-13). The results of the analyses and interpretations have been amply presented in the conclusions and also discussed in the stratigraphy sections under the geologic periods and/or formations. For additional details please refer to the original lab reports (Byington, 1973 and Harwood, 1975) located in Appendix B (Encl. 14).

The poor quality of the source rocks in the western portion of the basin must be due to surface weathering which affects every measurable parameter. For example, an expected vertical diagenesis pattern should show higher maturity with depth, however, the samples on the east flank of the Talkeetna Mountains reverse this pattern showing advanced maturity in the youngest rocks and pregeneration at the oldest levels (see source rock data on Talkeetna Mountains composite section, Encl. 3).

It is also noted that the scale by visual analysis of the kerogen is almost always one and sometimes two rating numbers less when the carbonization by elemental analysis is high and sometimes the reverse occurs when the elemental shows low maturity.

Additional samples giving a better representation for the formations of the western area, were collected during July, 1976 and submitted to the lab. The results are not yet in. Following is a table showing the hydrocarbon generating abilities by ages:

Period

Tertiary

Upper Cretaceous

Lower Cretaceous (Albian)

Lower Cretaceous (Neocomian)

Upper Jurassic (OxfordianKimmeridgian)

Upper Jurassic (Callovian)

Middle Jurassic
Hydrocarbon Generating Capability and Type

Good, (G)

nonsource

Good, (W)

Fair $(O, G, G, W)$

Poor $(O, O, G, G, G, G, G, G$,

$G, G, G, G$ )

Nonsource $(O, G, G, G)$

Very good $(G, W)$

Good $(W, W)$

Fair $(O, G, G)$

Nonsource $(W)$

Faix $(G, W)$

Poor $(G, G)$

Nonsource $(O, O, G, W)$

Poor $(0,0,0,0, G)$

Nonsource $(O, G, G, W)$

Fair (0)

Nonsource $(0, G)$

Very Good $(0, W)$

Poor (W)

Nonsource (G)
No. of Diagensis Samples Stage

\section{Pregen \\ 1 Peak}

1 Early Peak-Peak

4 Early Peak-Past

Peak

Early Gen-Adv

Early Gen-Past Peak

Early Peak to Early Adv.

2 Early Peak to Peak

3 Past Peak

1 Pastk Peak

2 Early Gen, to Early peak

2 Early Generation

4* Pregeneration

5 Past Peak Oil

4 Pregen.-Early Peak

1 Pregeneration

2 Pregeneration

2 Pregen-Past Peak

1 Early Generation

1 Pregeneration 
$\underline{\text { Period }}$

Lower Jurassic

Permian

Total Samples

Hydrocarbon Generating No. of Diagensis Capability and Type Samples stage

Poor $(0,0)$

Nonsource $(O, G, G)$

Good (G)

Fair (G)
Late Peak

Peak-Past Peak

$1 \quad$ Advanced

1 Advanced

Very Good (1 oil, 1 gas, 2 wet) 4

Good (2 gas, 3 wet) 5

Fair (3 oil, 6 gas, 2 wet) 11

Poor (8 oil, 13 gas, 1 wet) 22

Nonsource ( 7 oil, 10 gas, 3 wet) $\frac{20}{62}$

$0=$ oil, $\mathrm{G}=$ Gas, $\mathrm{W}=$ Wet Gas

*Includes one sample with insufficient Kerogen recovery to analyze. 


\section{AMOCO PRODUCTION COMPANY \\ RESEARCH CENTER}

SOURCE ROCK EVALUATION

Cret.\& Jur. Cuttings Spls.. Mobil 非 Salmon Berry Lake, Pan An 非 Moose Crk。, Copper R. Basin, Alasika

Geochemistry Group

R. M. Byington

Distribution: P. H. Garrison

T. Cooper, Attn.: R. Neil

Chief Geologist

W. R. Walton

J. A. Momper
Technical Services $8642 \mathrm{CR}+8649 \mathrm{CR}$

Jobs $9493+9490$

Requested by P. H. Garrison

Division : DENVER

Ka, (

40 


\section{INTRODUCTION}

The Denver Division requested source rock analyses on two wildcat we11s in the Copper River Basin, Alaska. Well cuttings samples to be analyzed were from the Nobil $k_{1}$ Salmon Berry Lake Unit, Sec. 24T6N-R6W CRM and the Pan American 非 Moose Creek, Sec. 29-T4N-R3W CRM. The samples are of Upper to Lower Cretaceous and Jurassic age. The analytical data and interpretation included in this report cover both Technical Services $8642 \mathrm{CR}$ and $8649 \mathrm{CR}$ and is part of a comprehensive study by the Denver Division of the petroleum potential of the Copper River Basin.

\section{SUMMARY}

Shale samples of the Upper and Lower Cretaceous of the Pan American 非 Moose Creek are generally deficient in organic matter and are shown to have a NON-SOURCE to POOR hydrocarbon generating capability. Samples of Lower Cretaceous age from the Mobil 非 Salmon Berry Lake indicate a FATR capability. The Jurassic shole samples fiom this well are rated NON-SOURCE to POOR. Based on visual (microscopic) kerogen analysis, the samples from both wells appear to contain principally a gas or gascondensate type kerogen that is indicated to be at EARLY GENERATION for gas.

\section{DISCUSSION}

Pan American 非1 Moose Creek (TS 8642CR)

The hydrocarbon generating capability of the U. Cretaceous Matanuska shale varies from NON-SOURCE to POOR through the sampled section from $600 "$ to 4720". The L. Cretaceous Nelchina shale sample is shown to have a NON-SOURCE rating due to the deficiency of organic matter. The hydrocarbon type that would be generated from this Upper and Lower Cretaceous sampled section, having sufficient organic matter content, is indicated to be principally GAS or GAS-CONDENSATE by both visual (microscopic) kerogen and elemental (?) analyses (Tables $2+3$ ). The stage of oxganic diagenesis for all samples, as shown by visual kerogen analysis (Table 3 ) of the sampled section is indicative of 
Techicai Services $8542 \mathrm{CR}$ and $8649 \mathrm{CR}$

EARLY GENERATION for gas and near PEAK GENERATION for oil (scale 4-5, or approximately $79-81$ wt \% C).

The extractables, with the exception of the Nelchina $(\mathrm{R}-66$,$) a11 appear$ to contain appreciable amounts of a non-crude oil-like contaminant, as indicated by heavy hydrocarbon distribution plots (Tigs. 2-A).

The L. Cretaceous Nelchina extract from sha1e sanple 6460' $6540^{\circ}(\mathrm{R}-66)$ is representative of a natural crude and suggests a 1iquid hydrocarbon capability for this zone. This, however, appears to be in conflict with the gas-type kerogen as denoted by visual kerogen analysis (Table 3). Although the elemental analyses (Table 2) are subject to question because of probably incomplete sample purification, it is interesting to note that the hydrogen value ( 6.5 wt \%) of $\mathrm{R}-66$ is significantly higher than that of the shallower samples. This fact points to a possible oil capability along with the gas for L. Cretaceous sample R-66.

Mobil 非 Salmon Berry Lake (TS 8649CR)

The L. Cretaceous shale samples from $2020^{\circ}$ to $2450^{\prime}$ show a FATR hydrocarbon generating capability based on wt \% of organic carbon (Table 1). These shales contain a GAS to GAS-CONDENSATE type kerogen, as shown by visual kerogen analysis (Table 3). The stage of diagenesis, as shown by the visual analysis is indicative of EARLY GENERATION for gas. Unfortunately, a determination of the diagenetic stage from elemental analyses is hampered by excessive oxygen values, probably resulting from incomplete purification of the kerogen samples.

The Jurassic shale sample from $4790^{\circ}$ to $5190^{\prime}$ shows a. POOR hydrocarbon generating capability (Table 1). Jurassic samples from $6640^{\circ}$ to $7670^{\prime}$ are rated as NON-SOURCES of hydrocarbons due to insufficient amounts of organic matter (<0.4 wt \% organic carbon, Table 1$)$. These shales appear to contain a gas-condensate type kerogen, as indicated by visual kerogen analysis (R-7.5, Table 3). The stage of organic diagenesis, as shown by the visual analysis is indicative of EARLY GENERATION for gas.

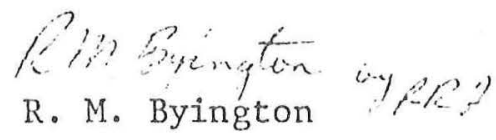




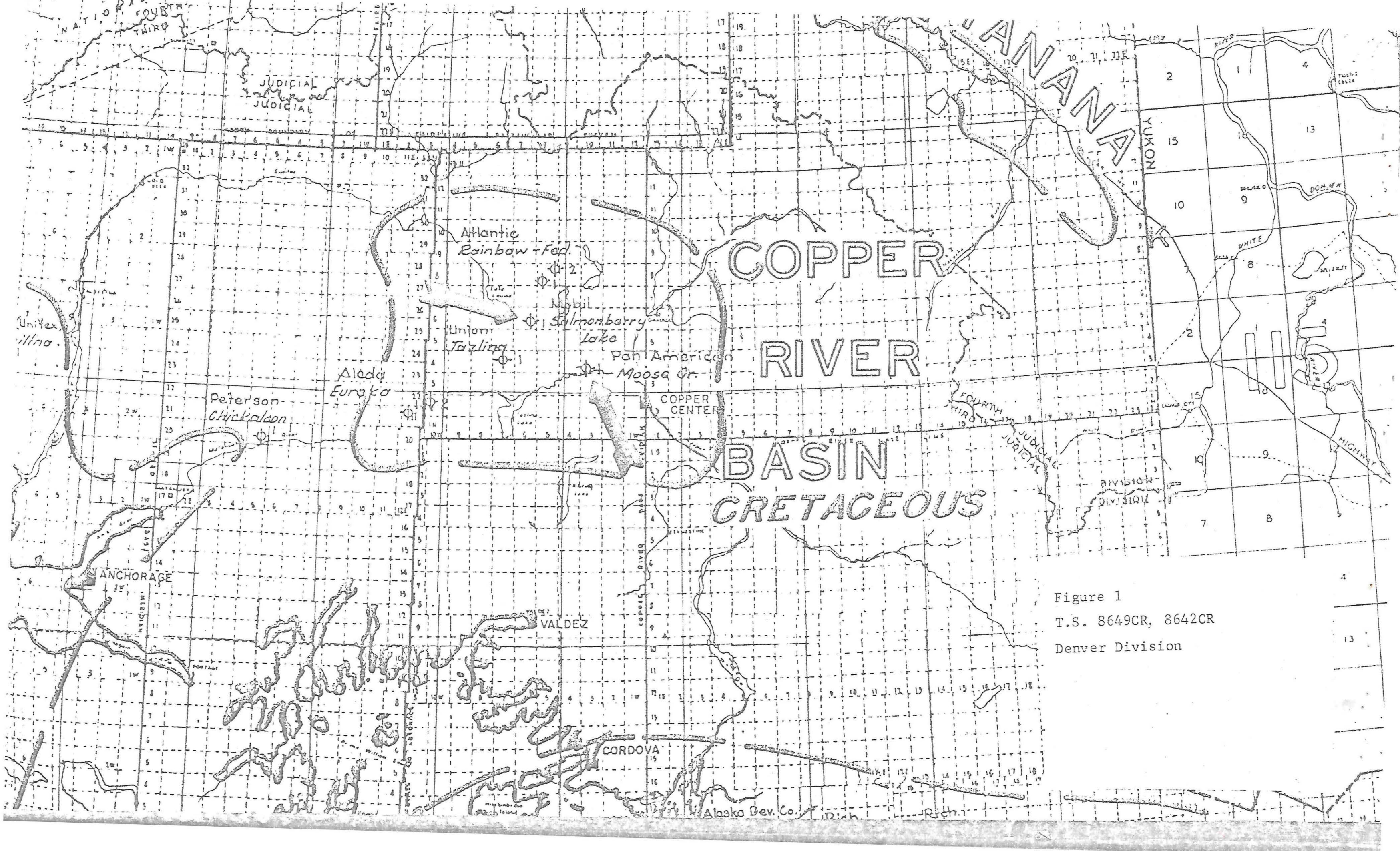


OPFICE_ Denver

AUTHORIZEO BY P.H. Garrison

PECHNICAL SERVICE NUMBER 8642CR

SPATE_Alaska
AREA Copper R. Basin

DAPE

\section{AMOCO PRODUEIION COMPANY \\ RESEARCH CENTER}

- SOUREE ROCK EVALUATION

\begin{tabular}{|c|c|c|c|c|c|c|c|c|c|c|c|c|}
\hline \multicolumn{2}{|c|}{ SAMPLE } & \multirow{2}{*}{ FORMATION } & \multirow{2}{*}{$20 \%$} & \multirow{2}{*}{ LTHOLOOY } & \multirow{2}{*}{ DEPTH F } & \multirow{2}{*}{ FT } & \multirow{2}{*}{$\begin{array}{l}\text { INSOLUSLE } \\
\text { RESIDUE \% }\end{array}$} & \multirow{2}{*}{$\begin{array}{l}\text { TOTAL OAGAMIC } \\
\text { CARBON WT. \% }\end{array}$} & \multirow{2}{*}{$\begin{array}{l}\text { EXTRACTAELE } \\
\text { ORCANIC } \\
\text { BEL /ACRE FT. }\end{array}$} & \multirow{2}{*}{$\begin{array}{l}\text { EXTRACTABLE } \\
\text { MOROCARBON } \\
\text { BEL /ACRE FT. }\end{array}$} & \multirow{2}{*}{ 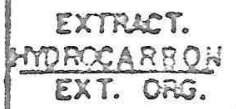 } & \multirow{2}{*}{$\begin{array}{l}\text { EXTRACT. } \\
\text { OPGANIC } \\
\text { FOTAL ORG. }\end{array}$} \\
\hline MUMBER & TYPE & & & & & & & & & & & \\
\hline
\end{tabular}

Cogduti Pan American 非 Moose Crk. Sec. 29-T4N-R3W

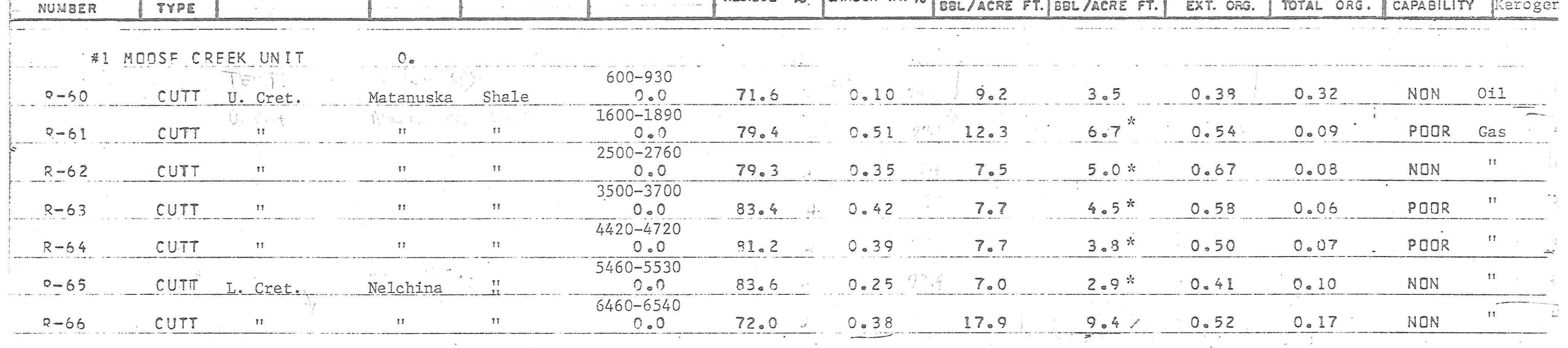

*Heavy hydrocarbon distribution plots (Figs. 2-4) indicate that these extracts are contaminated

with_a non-crude oil-like substance 
OFFICE

Denver

AUTHORIZED BY P. H. Garrison

AREA Copper R. Basin

DATE

TECHNICAL SERVICE NUMGER 8649CR

STATE Alaska

COUNTY
AMOCO PRONU6710N CONBANY

RESEARCH CENTER

SOUVICE ROCK EVALUGITION

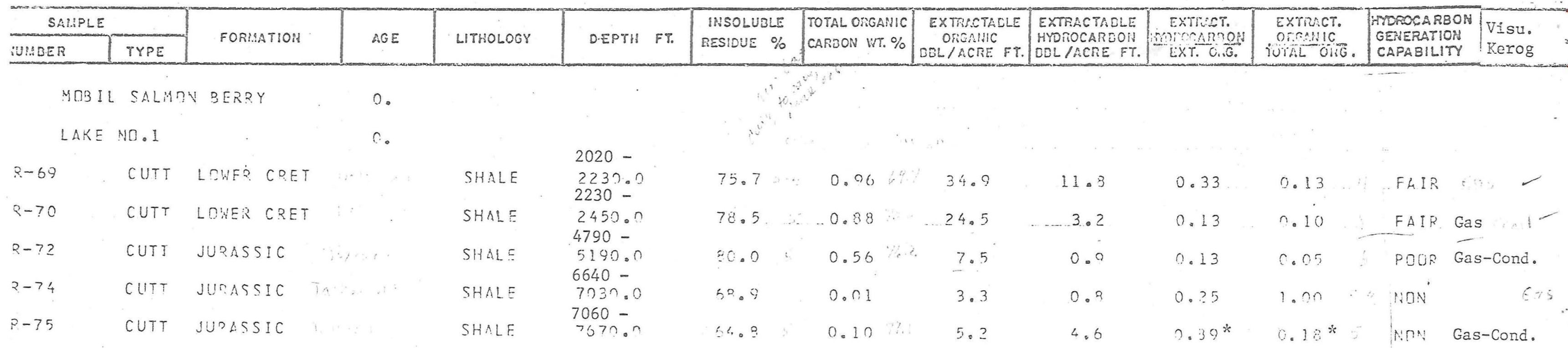

*Ratios indicate the presence of migrated oil

Note: No analyses run on spls. $3820^{\prime \prime}-4210$ because of severe cave problem (binocular microscopic exam. RMB)

Prelim. Rept. Telecon, Byington to R. A. Neil, 2-15-73

TS8642CR + TS8644CR)

Table Ib.

TS $8649 \mathrm{CR}$

f a wiebines by pht 


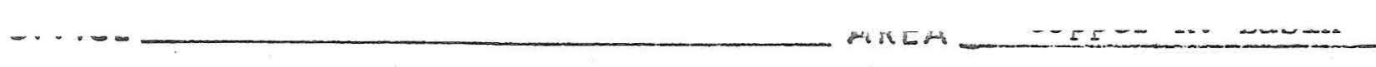

AUTHORIZED BY P. H, Garrison DATE

TECHNICAL SERVICE NUMBER $8642 \mathrm{CR}+8649 \mathrm{CR}$

STATE (PROVINCE) Alaska COUNTY

\begin{tabular}{|c|c|c|c|c|c|}
\hline \multicolumn{3}{|c|}{ SALAPLE } & \multirow{2}{*}{ FORRATION } & \multirow{2}{*}{ LITHOLOGY } & \multirow{2}{*}{ DEPTH } \\
\hline NULAER & PYPE & QUaLITY & & & \\
\hline & $\mathrm{BHT}$ & $130^{\circ} \mathrm{F}$ d & $7865^{\circ}$ Pan American & \#1 Moose Crk & Sec. $29-T 49$ \\
\hline$R-60$ & $\begin{array}{l}\text { Cut- } \\
\text { tings }\end{array}$ & & $\begin{array}{l}\text { Matanuska } \\
\text { (U. Cret.) }\end{array}$ & H. Gry. Sh. & $600-930$ \\
\hline $\mathrm{R}-61$ & " & $\cdots$ & $"$ & $11+\operatorname{SS}(10 \%)$ & $1600-1830$ \\
\hline $\mathrm{R}-62$ & $"$ & & $"$ & $" I+\operatorname{SS}(5 \%)$ & $2500-2760$ \\
\hline$R-63$ & $"$ & & $"$ & $"$ + SS $(10 \%)$ & $3500-3700$ \\
\hline$R-64$ & $"$ & & $"$ & $"$ +SS $(5 \%)$ & $4420-4720$ \\
\hline $\mathrm{R}-65$ & $"$ & & $"$ & $"$ & $5460-5530$ \\
\hline$R-66$ & $" n$ & & Nelchina ( L. Cr. $_{\text {) }}$ & " " & $6460-6540$ \\
\hline & BHT & $126^{\circ} \mathrm{F}$ d & 7912 Mobil ti 1 Sall & hon Berry Lake & Unit Sec. 24 \\
\hline $\mathrm{R}-69$ & $"$ & & L. Cret. & $\begin{array}{l}\text { Hvy . Gry. } \\
\text { Slty. Sh. }\end{array}$ & $2020-2230$ \\
\hline $\mathrm{R}-70$ & $"$ & & $"$ & " & $2230-2450$ \\
\hline $\mathrm{R}-72$ & "1 & & Jurassic & Gr. Sh. & $4790-5190$ \\
\hline $\mathrm{R}-74$ & & & $"$ & $\begin{array}{l}\text { Gry. Sh., } \\
\text { Grn. SIty. Sh }\end{array}$ & $6640-7030$ \\
\hline$R-75$ & & & L. Jurassic & Vari-Col. Sh. & 7060 \\
\hline
\end{tabular}

REMARKS:
Amoco Production Company

RESEARCH CEPTER

ORGANIC DIAGENESIS OATA

WELL LOCATION

\begin{tabular}{|c|c|c|c|c|c|c|c|}
\hline \multicolumn{4}{|c|}{ ELESERTRL AUELYSIS, PERCENT } & \multirow{2}{*}{$\begin{array}{c}R A 710 \\
H / C\end{array}$} & \multirow{2}{*}{$\begin{array}{l}\text { INTERPRETED STATH } \\
\text { OF DIAGENESIS }\end{array}$} & \multicolumn{2}{|c|}{ KYONOCAREOH TYPE BY } \\
\hline CARBON & HYOROGEH & OXYGEN & MITBOCES & & & $\%$ HYOROEED & Vis.Kerog. \\
\hline$R 3 W(T S$ & $8642 \mathrm{CR})$ & & & & & & \\
\hline 75.5 & 4.7 .1 & 18.6 & 0.6 & 0.75 & . & Prob. Gas & oil. \\
\hline 77.1 & 4.8 & 16.2 & 2.0 & 0.74 & & " & Gas \\
\hline 77.4 & 5.1 & 15,4 & 2.2 & 0.79 & & $"$ & "I \\
\hline 75.7 & 5.2 & 16.8 & 2.3 & 0.83 & & $"$ & $n$ \\
\hline 78.9 & 5.5 & 13.1 & 2.5 & 0.84 & & $"$ & $" 1$ \\
\hline 72.4 & 4.9 & 20.5 & 2.2 & 0.82 & & $" 1$ & il \\
\hline 76.2 & 6.5 & 15.7 & 1.6 & 1.02 & & $"$ & :" \\
\hline$-6 \mathrm{~N}-6 \mathrm{~W}$ & $S 8649 \mathrm{CR})$ & & & & & & \\
\hline 69.7 & 5.1 & 23.7 & 1.3 & 0.88 & & Prob.Gas & Gas \\
\hline 70.5 & 5.1 & 22.6 & 1.5 & 0.88 & & $"$ & Gas-Cond. \\
\hline 76.2 & 3.8 & 17.5 & 2.2 & 0.61 & & $"$ & $" n$ \\
\hline Insuffic & ient $\mathrm{sp} I$. & for anal & ysis & & & & Gas \\
\hline 79.1 & 4.5 & 15.7 & 0.6 & 0.69 & & Prob.Gas & Gas-Cond. \\
\hline
\end{tabular}

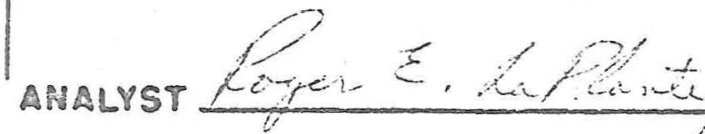




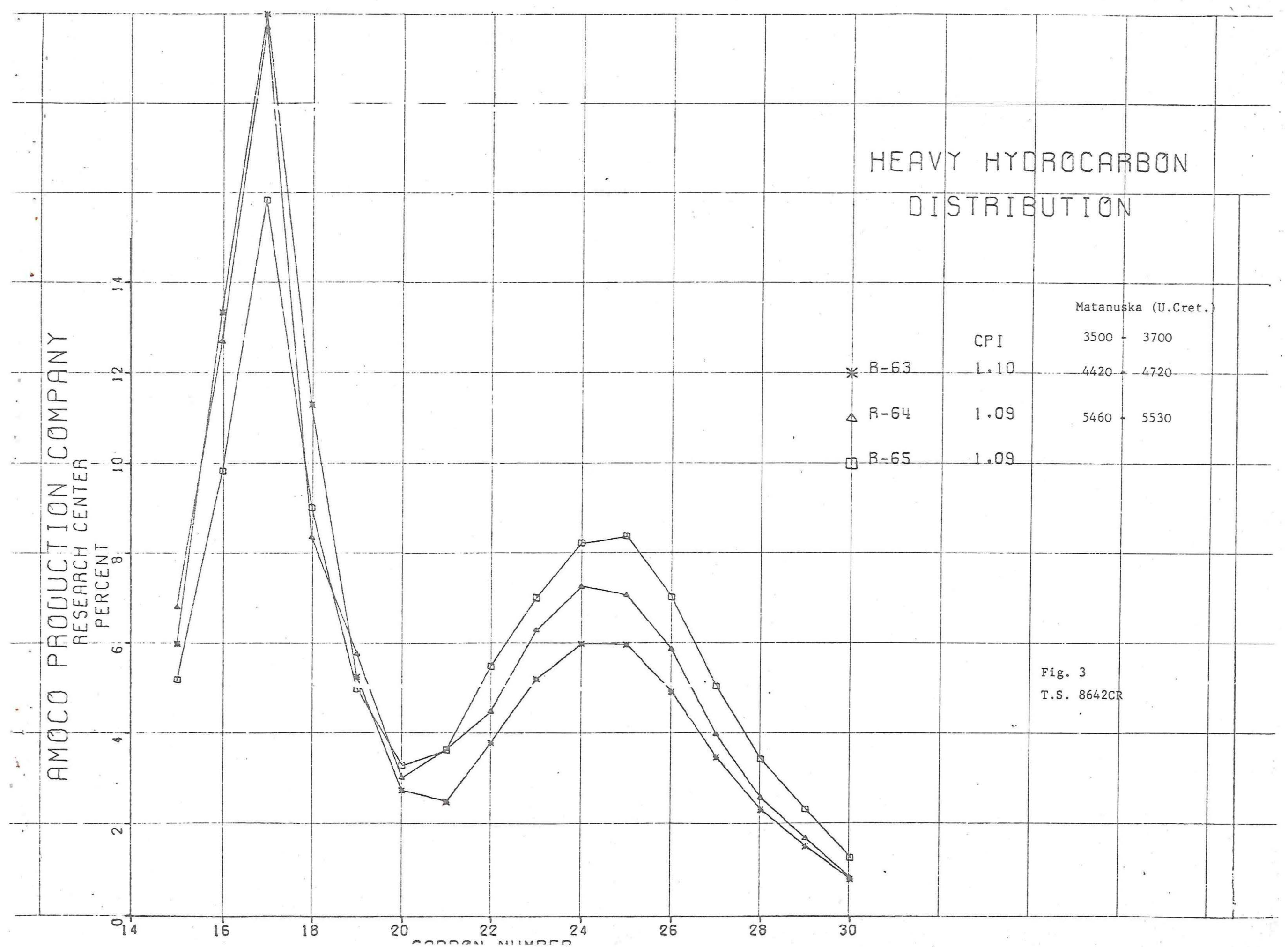




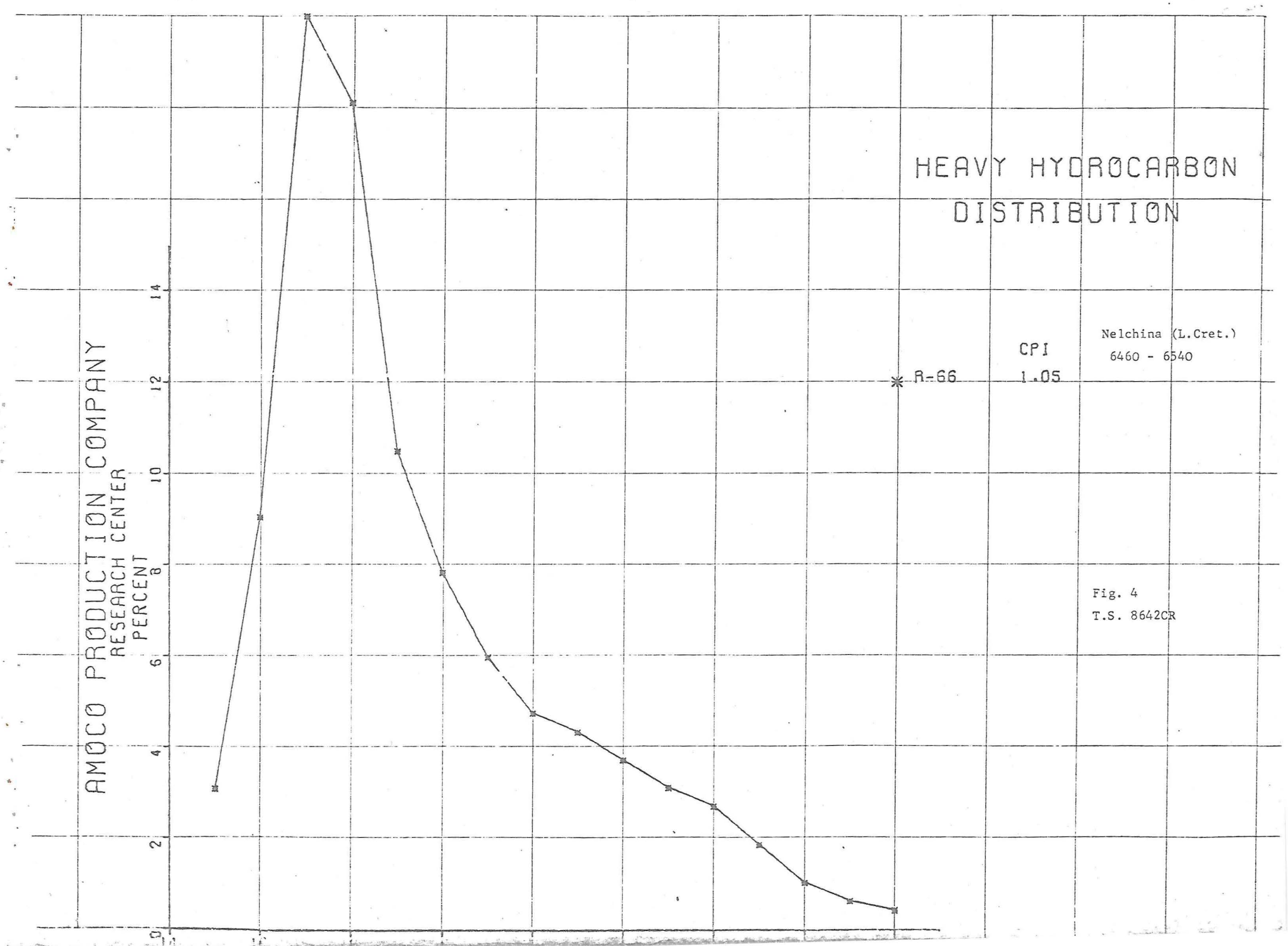




\section{Division: Denver}

Well Name: Pan American 非 Moose Crk.

Iocation: Sec. 29-T4N-R3W

State or Country: Alaska

Geol. Province: Copper R. Basin

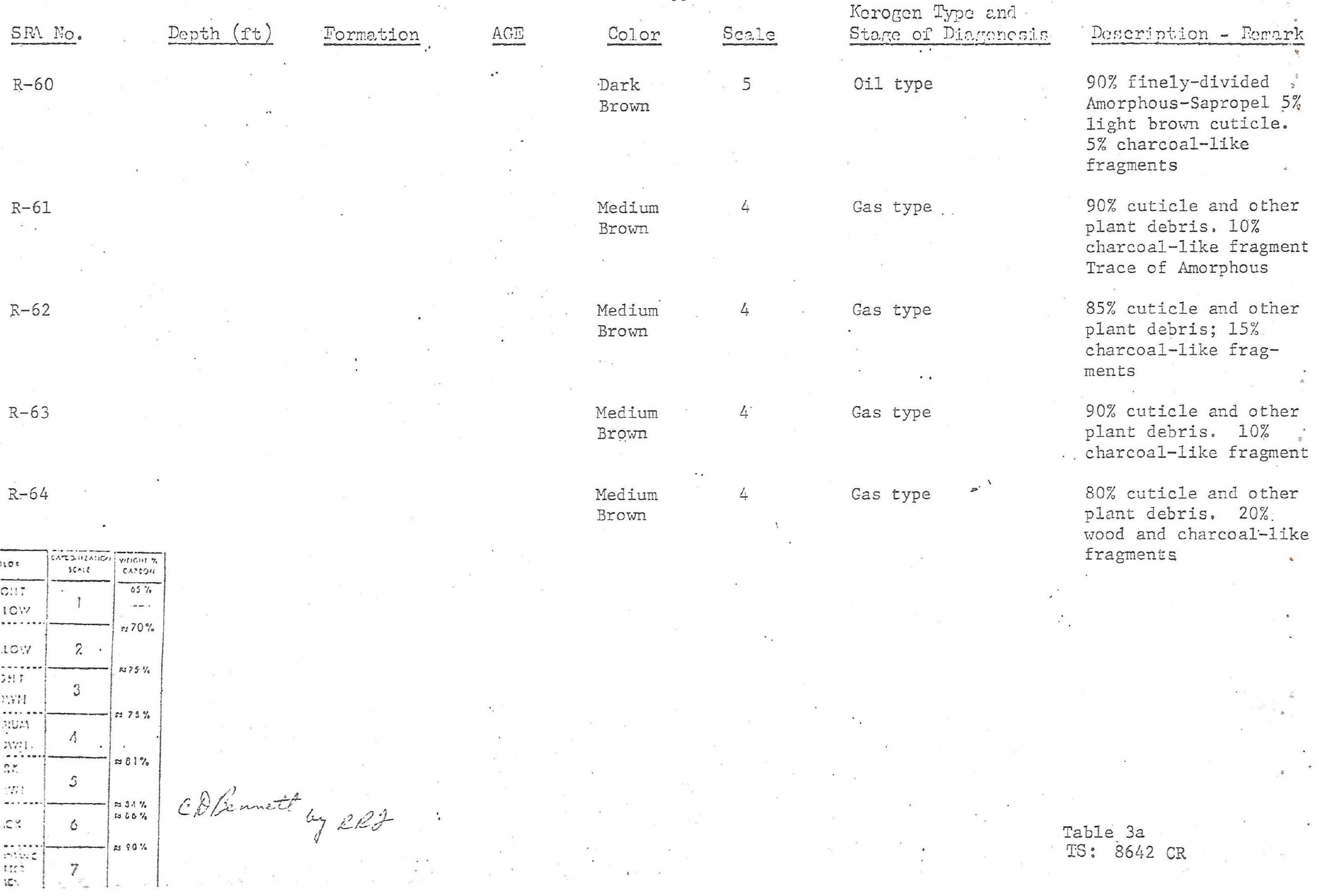


Locstion:

State or Country:

Geol. 'Mrovince:

\section{SEA NOO. \\ Depth (ft) Tormation \\ AGP \\ Color \\ Kerogen Trpe and}

$R-65$

$R-66$
Medium

Brown

4.

Stare of Diaremesis

Gas: type

Medium

Brown
Gas type
Descrintion - Rema

$75 \%$ cuticle and

other plant debris.

$20 \%$ charcoal-like

fragmerits. $5 \%$

amorphous material

$90 \%$ cuticle and

other plant debris.

$5 \%$ amorphous mater-

ial; $5 \%$ charcoal-

like fragments

Table 3b。

TS: $8642 \mathrm{CR}$ 


\section{Division: Denver}

Well Name: Mobil 非 Berry Lake Unit

Iocation:

State or Country:

Alaska

col. Province:

\begin{tabular}{|c|c|c|c|c|c|}
\hline SBN No. & Depth (ft) & Formation & AGS & Color & Scale \\
\hline$R-69$ & . & & . & $\begin{array}{l}\text { Light } t \\
\text { Medium } \\
\text { Brown }\end{array}$ & $3-4$ \\
\hline
\end{tabular}

Kerogen Type and

ane of Dimmencsis

Deccription - Romary

cuticle and othar plant debris. $15 \%$ amorphous; $15 \%$ wood and charcoal-like fragments. Dark brown (reworked?)

material present $20 \%$.

\begin{tabular}{|c|c|c|}
\hline 60102 & 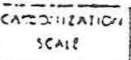 & 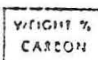 \\
\hline $\begin{array}{l}\text { Uent? } \\
\text { Etoow }\end{array}$ & 1 & $05 \%$ \\
\hline EL:O:Y & ?. & \\
\hline $\begin{array}{l}10: 11 \\
0.914\end{array}$ & 3 & No75\% \\
\hline $\begin{array}{l}\text { colus } \\
\text { Bewn }\end{array}$ & 4 & $\approx 78 \%$ \\
\hline an & 5 & $\approx 81 \%$ \\
\hline mes & 6 & $\approx 00 \%$ \\
\hline 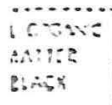 & 7 & × $90 \%$ \\
\hline
\end{tabular}




\section{Division:}

Well Nane:

Locat10n:

State or Country:

Geol. Province:

SRA NO

Depth (ft) Formarion

$R-75$

Age

Col

Dark
Brown
$120.0 \mathrm{X}$
30.3

30.3
Scale Kerogen Type

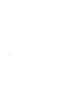

Gas Condensate

* Successive sieving showing the finely-divided material was amorphous.

\section{Descriotion - Remarks}

$* 60 \%$ finely-divided amorphousSaprope1; $40 \%$ carbonized cuticle. Observed 2 scales $4 \& 5$. Believe 5 to be indigenous

\begin{tabular}{|c|c|c|}
\hline 50102 & 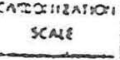 & $\begin{array}{l}\text { Yrowt } \\
\text { CAROON" }\end{array}$ \\
\hline $\begin{array}{l}\text { HG:IT } \\
\text { YELLOW }\end{array}$ & $i^{-}$ & $63 \%$ \\
\hline YELLOW & 2.. & \\
\hline $\begin{array}{l}110 \mathrm{HT} \\
\mathrm{DrO}: \mathrm{WN}\end{array}$ & 3 & $\approx 75 \%$ \\
\hline $\begin{array}{l}\text { MentuA } \\
\text { BRown }\end{array}$ & $\Lambda$ & 78 \\
\hline $\begin{array}{l}\text { DRIR } \\
\text { DRONN }\end{array}$ & 5 & 815 \\
\hline $\operatorname{sinck}$ & 0 & \\
\hline 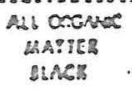 & 7 & 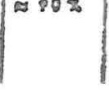 \\
\hline
\end{tabular}




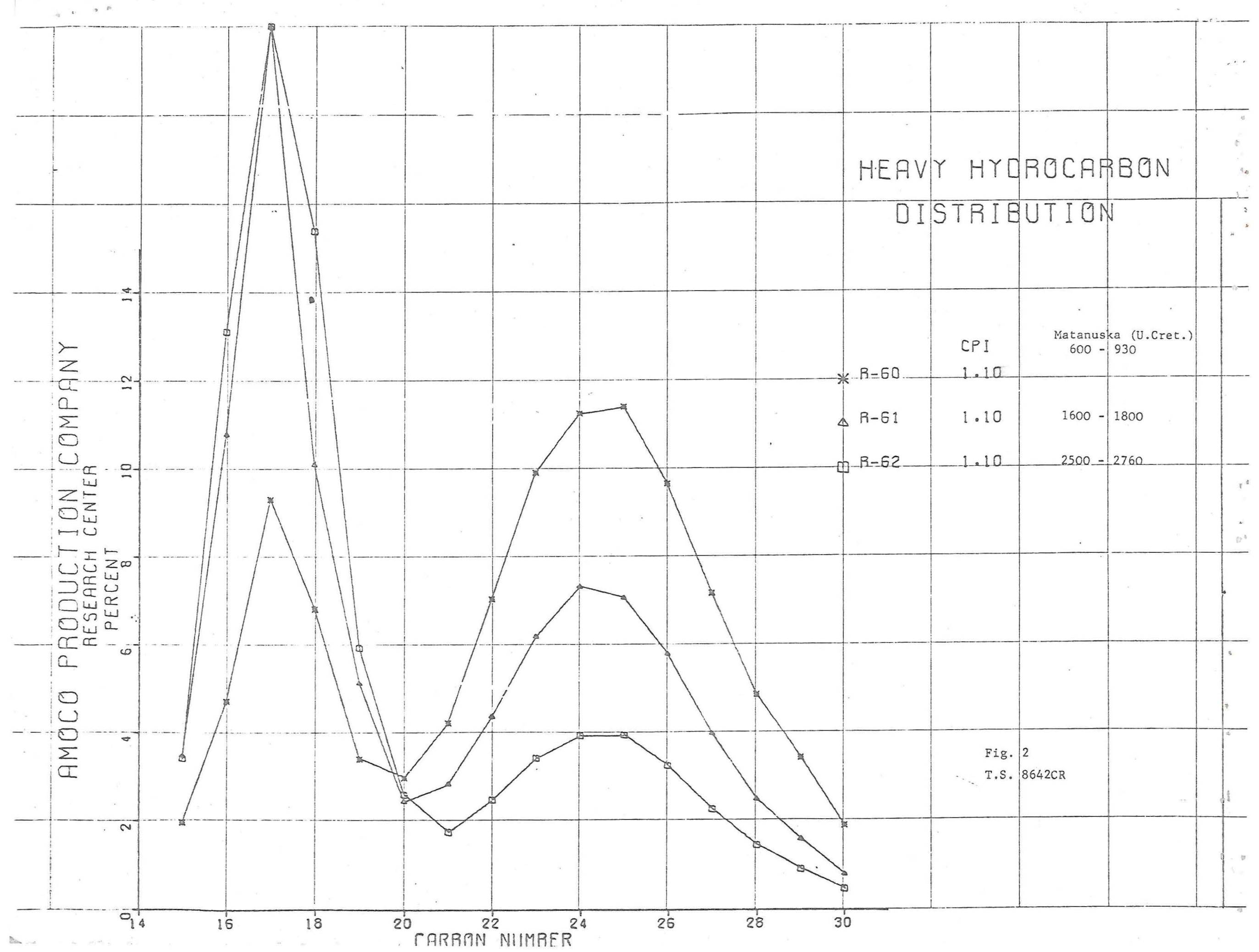




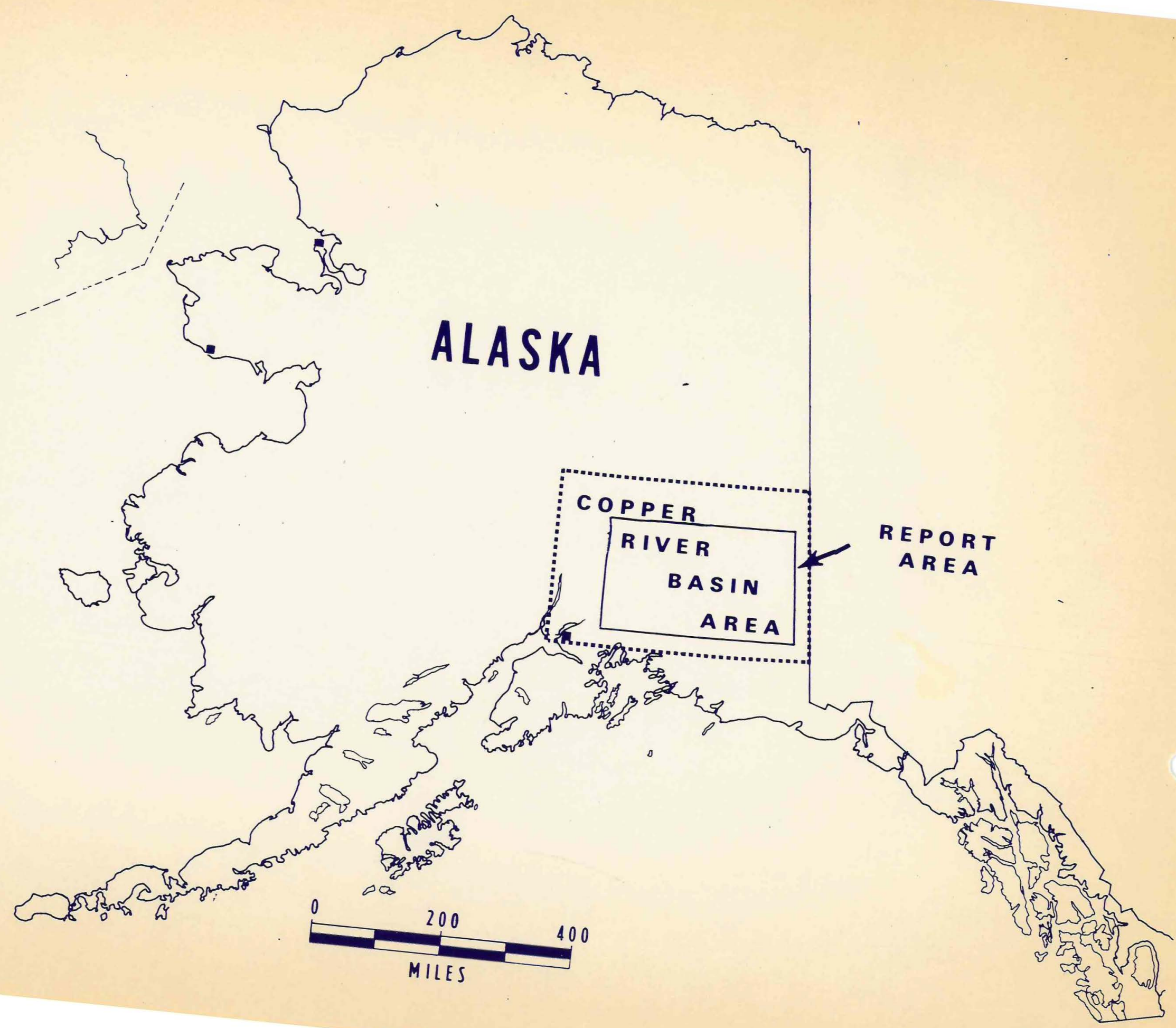

Fig. 1 